\title{
Türkiye'de Öğrenme Amaçlı Yazma Hakkında Yapılan Araştırmaların Analizi: Bir Meta-Sentez Çalışması
}

\author{
DOI: $10.26466 /$ opus.906264
}

$*$

\author{
Bünyamin Ispir * \\ * Doktora Öğr., Atatürk Üniversitesi, Eğitim Bilimleri Enstitüsü, Erzurum/Türkiye \\ E-Posta: bünyamin.ispir14@org.atauni.edu.tr ORCID: 0000-0002-0428-8887 \\ ** Prof. Dr., Atatürk Üniversitesi, Eğitim Fakültesi, Erzurum/Türkiye \\ E-Posta: ayildiz@atauni.edu.tr \\ ORCID: $\quad \underline{0000-0001-6241-2316}$
}

Öz

Çalışmanın amacı, Türkiye'de öğrenme amaçl yazma ile ilgili yapılmış araştırmaları meta-sentez yöntemi ile analiz ederek belirlenen kriterlere göre nasıl bir dağılım gösterdiğini saptamaktır. Çalışma kapsamında 2020 yılının sonuna kadar yapılmış 45 tez ve 22 makale analiz edilmiştir. Araştırmaların seçiminde Yüksek Öğretim Kurumu Ulusal Tez Merkezi ve Ulakbim (TR Dizin) veri tabanlarından faydalanılmıştır. Tarama sonucunda ulaşılan tez ve makaleler incelenmiş ve öğrenme amaçl yazma hakkında gerçekleştirilen araştırmalar çalışma kapsamına dâhil edilmiştir. Tez ve makalelerin her biri içerik analizine tabi tutularak araştırmalar; yıl, üniversite ve enstitü, amaç, yöntem, konu alanı, örneklem kademesi, sinıf düzeyi, örneklem büyüklüğ̈̈, veri toplama aracl, uygulama süresi, istatiksel analiz, doküman türü, çalışma yeri, çalışma bölgesi, varılan sonuç ve kaynak sayısı açısından incelenmiştir. Elde edilen verilerin yorumlanmasında frekans, yüzde, grafik ve tablolar kullanılmıştır. Çalışmada, araştırmaların büyük bir bölümünün son yıllarda ve eğitim bilimleri enstitülerinde gerçekleştirildiği; akademik başarı, tutum ve öğrenmeyi ölçmenin hedeflendiği; daha çok nicel yöntemin tercih edildiği; uygulamaların gerçekleştirildiği konuların yoğun olarak fen bilimleri, örneklem kademesinin ise ortaokul olduğu; 6. sinıflarla yapılan araştırmaların yoğunluk gösterdiği ve genelde 26-50 ile 51-75 aralığında örneklemin kullanıldığı belirlenmiştir. Ayrıca ölçek, anket ve başarı testleri gibi veri toplama araçlarının fazla kullanıldığl; araştırmaların daha çok 5-7 hafta arasında, il merkezlerinde ve Doğu Anadolu Bölgesi'nde gerçekleştirildiği; genelde doküman türü olarak tezlerin, istatistiksel analiz olarak parametrik testlerin kullanildığ sayısının daha fazla öne çıtı̆̆̆ saptanmıştır.

Anahtar Kelimeler: Öğrenme amaçl yazma, meta-sentez, doküman incelemesi. 
ISSN:2528-9527

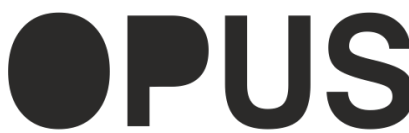

E-ISSN: 2528-9535

Yıl Year: 11

Cilt Volume: 18

Sayı Issue :41

Uluslararası Toplum Araştırmaları Dergisi International Journal of Society Researches

Eylül September 2021

Makalenin Geliş Tarihi Received Date: 30/03/2021 Makalenin Kabul Tarihi Accepted Date: 03/06/2021

\title{
An Analysis of the Researches on Writing to Learn in Turkey: A Meta-Synthesis Study
}

$*$

\begin{abstract}
The purpose of the study is to analyze the theses and articles on writing to learn in Turkey through meta-synthesis method and determine how they are distributed according to set criteria. Within the scope of the study, 45 theses and 22 articles, which were carried out until the end of 2020, were analyzed. Higher Education Institution National Thesis Center and Ulakbim (TR Index) databases were used in the selection of the researches. The theses and articles obtained as a result of the reviewing were examined and the researches about writing for learning purposes were included in the study. Each of the theses and articles were subjected to content analysis, and research studies were examined in terms of year, university and institute, purpose, method, subject area, sampling level, grade level, sample size, data collection tool, duration of application, statistical analysis, document type, place of study, study region, the conclusion and the number of references. In the study, it was determined that most of the research was carried out in recent years and in educational sciences institutes, the purpose was to measure academic achievement, attitude and learning, quantitative method was mostly preferred, the subjects in which the applications were carried out were mainly science, and the sampling stage was secondary school, the studies conducted with the 6th graders showed intensity and the sample was generally between 26-50 and 51-75. In addition, it was observed that data collection tools such as scale, questionnaire and achievement tests were used excessively; the researches were mostly carried out in 5-7 weeks in the city center and Eastern Anatolia Region, thesis was used as document type and parametric tests were used as statistical analysis and the number of sources between 51-100 was more prominent in the studies.
\end{abstract}

Keywords: Writing to learn, meta-synthesis, document analysis. 


\section{Giriş}

Bilim ve teknolojide sınırları zorlayan gelişmeler yaşanmakta ve buna bağlı olarak bilimsel çalışmalar hız kazanmaktadır (Aydın, 2018). Bu gelişmelerin neticesinde bireylerde bulunması gereken özelliklerle ilgili düşünceler farklılık göstermektedir (Tümay ve Köseoğlu, 2011). Bundan dolayı kavramlar arası ilişki kurabilme, muhakeme edebilme ve problem çözebilme gibi becerilerin bireylerde var olmasına önem verilmiştir. Ayrıca 21. yüzyıl becerileri olarak kabul edilen benzer becerilerin, bireylerin kişisel gelişimleri için çok önemli olduğu vurgulanmıştır (Çakan-Akkaş ve Kabataş-Memiş, 2020; Özyurt, 2011). Bu yüzden günümüzde eğitimin en önemli hedefi; 'problem çözme, iletişim kurma, akıl yürütme, eleştirel düşünme ve yaratıcılık gibi öğrenme becerileri ile girişimcilik, üretkenlik ve sorumluluk gibi yaşam becerilerini ve bilim okuryazarlığı gibi bilgi becerilerini bireylere kazandırmak' olmalıdır.

Geleneksel öğretim yaklaşımları, bireylerde bulunması gereken bu becerileri kazandırmada yetersiz kaldığından çağdaş öğretim yaklaşımları, geleneksel öğretimin yerini almaya başlamıştır (Erduran ve Akçay, 2013; Takaç, 2019). Günümüz çağdaş eğitim yaklaşımları; öğrencileri ezbere sürükleyen ve onlara bilgiyi kalıplar halinde sunan geleneksel eğitim görüşünden (Erol, 2010) ayrılarak öğrencinin etkin, öğretmenin ise yönlendirici ve yeni bilgilere ulaşmada öğrenciye 1şık tutan bir role sahip olduğu anlayışı benimsemektedir (Ay, 2018; Balım, İnel ve Evrekli, 2007; Şahin, 2019). Bundan dolayı Milli Eğitim Bakanlığı'nın [MEB] öğretim programları için yürüttüğü çalışmalar, eğitim ortamının daha çok öğrenci merkezli olması ve yapılandırmacı yaklaşımı esas alması gerektiğini belirtmektedir (Bozat, 2014).

Bilginin bireyin dışında değil aksine bireye ait izler taşıyan öznel bir yapı olduğunu ifade eden yapılandırmacılık (Tarikdaroğlu, 2019), Giambatista Vico'nun 18. yy'da yaptığ 1 çalışmalara kadar uzanmaktadır. Vico'dan sonra İmmanual Kant onun görüşlerini geliştirerek bilgiyi oluşturmada insanın etkin olduğunu ortaya koymuştur ancak yapılandırmacılığa yönelik ilk önemli adımlar Piaget tarafından atılmıştır (Özden, 2020). Yapılandırmacı öğrenmede, birçok yaklaşımın tüm yönlerinin incelenmesinden ziyade bilişsel yapılandırmacılığı öne 
süren Piaget ile sosyal yapılandırmacılığı öne süren Vygotsky'nin çalışmaları üzerinde daha çok durulmuştur (Aydın, 2018).

Piaget, bilginin birey ile çevresinin aktif etkileşimi sonucu oluştuğunu varsayar ve bu görüşünü özümleme, uyma ve dengeleme süreçleriyle açılamaya çalışır. Ona göre birey, karşılaştığı yeni bir durumu geçmişteki deneyim ve bilgileriyle özümlemeye çalışır. Deneyim ve bilgilerin yetersiz olduğu durumlarda birey, bilişsel olarak yeni bir kavram oluşturarak duruma uyum sağlar ve yeni bir durumla karşılaşıldığında bozulan denge yeniden düzenlenmiş olur. Vygotsky ise Piaget'in aksine öğrenmenin bireyin yalnızca kendi başına gerçekleştirdiği bir süreç olmadığını ve öğrenmede sosyal etkileşim ve dilin önemli olduğunu vurgular (Özden, 2020).

Kuramdan kurama değişik şekillerde edinilen öğrenme; öğretmeye göre daha ön plandadır, bireysel ve aktif bir anlam oluşturma sürecidir, özneldir, kavramsal değişimi içerir, girişimciliği destekler, sosyal bir çalışmadır ve süreklidir gibi bir dizi özellikleri kapsar (Budak, 2016). Bu özelliklerin yürütülmesi ve sürdürülmesi doğrultusunda tüm dünyada günün gereksinimlerini karşılamak için öğretim programlarının felsefi arka planında değişikliğe gidilmiştir. Türkiye'de de 2005 yılında ilköğretim kademesinde radikal bir değişim gerçekleşmiş ve öğrencietkinlik merkezli yapılandırmacı yaklaşım benimsenmiştir (MEB, 2005).

MEB, öğretim programlarında ve eğitim sisteminde değişiklik yapmasına karşın, eğitimin öğrenciye kazandırılması istenen özellikler için gerekli imkânları sağlayıp sağlayamadığı tartışılan konular arasındadır (Demirel, Somyürek ve Yılmaz, 2017). Gerek ulusal gerekse uluslararası sınavlardan alınan sonuçlar, Türkiye'de öğrencilerin beklenilen başarıya ulaşamadıklarını göstermektedir. 2018-2019 eğitimöğretim yılında 8. sinfflara uygulanan Liselere Geçiş Sistemi'nde matematik başarı ortalaması 20 soruda 5,09 olarak, fen bilimlerinde ise 20 soruda 9,97 olarak saptanmıştır (MEB, 2019). Ayrıca Türkiye, 2018 yılında yapılan son PISA testinden alınan sonuçlara göre matematik, okuma ve fen bilimlerinde 37 OECD ülkesi içerisinde 31. sıraya yerleşerek OECD ülke başarılarının çok gerisinde kalmıştır (PISA, 2018). Yani günümüz eğitiminde öğrencilerin beklenen davranışları sergilemeleri ve istenen özellikleri benimsemeleri için yeni yaklaşımlar öne sürülmesine rağmen bu yaklaşımların eğitim-öğretim ortamına ve 
öğrencilere aktarılmasında problemlerle karşılaşılmaktadır. Bundan dolayı zorunlu olarak sistem, öğretmenleri farklı yöntem ve teknikleri kullanmaya teşvik etmektedir (Aydın, 2018). Bununla birlikte her öğrencinin birbirinden farklı öğrenme süreci yaşamasından dolayı bireysel farklılıklar ortaya çıkmakta ve bu farklılıklar günümüzde kullanılan yöntem ve tekniklerin çeşitlenmesini zorunlu kılmaktadır (Gülcü, 2019). Öğrenme amaçlı yazma, bu yöntem ve teknikler arasındadır (Daşdemir, 2017; Öztürk vd., 2016; Yıldız, 2009).

İnsanoğlunun yaşamı boyunca işittiği ve gözlemlediği tüm durumları kaydetmek, aktarmak veya başkalarının bunlardan yararlanmasını sağlamak için yazı yazmaya ihtiyaç duyulmuştur. Yazma, 'belirli bir konu ile ilgili tecrübe, yaşanmışlık ve duyguları dil bilgisi kurallarını gözeterek iletmek' şeklinde ifade edilebilir (Tarikdaroğlu,2019). Başka bir deyişle yazma, düşüncelerimizi, hislerimizi, tasarladıklarımızı ve gözlemlediklerimizi aktarmaktır (Sever, 2015). Ayrıca yazma, düşünce ve ifadeleri özel harf ve işaretlerle anlatmaktır (Türk Dil Kurumu [TDK], 2021). Ancak günümüzde yazma, işaretlerden ziyade öğrenmeyi ve zihnin kullanımını sağlayan bilişsel bir faaliyet olarak ifade edilebilir (Aktepe, 2020). Bundan dolay1 yazma, 21. yy'de eğitim sürecinin bir parçası olarak birçok ülkede kullanılmaktadır (Kavaklı, 2016).

Yazmanın öğrenme amaçlı kullanımı, Emig'in çalışmalarına kadar uzanmaktadır (Kavaklı, 2016). Emig'e (1977) göre dil süreçleri dinleme, konuşma, yazma ve okumadan oluşmaktadır. Bu süreçler iki temel grup altında sınıflandırılmaktadır. Dinleme ve konuşmadan oluşan birinci grup informal yollarla kazanılırken yazma ve okumadan oluşan ikinci grup formal eğitim yoluyla kazanılmaktadır. İnformal yollarla kazanılan konuşma ve dinlemeden oldukça farklı olan okuma ve yazma, sistematik ve planlı bir eğitim sonucunda kazanılan öğretilerdir (Sağırlı-Özturan, 2010). Çünkü okuma ve yazma, konuşma ve dinlemeye nazaran bireyin duyuşsal, devinişsel ve mental olarak aktif olması gerektiği çok yönlü bir beceridir (Aktepe, 2020; Tarikdaroğlu, 2019). Ayrıca yazma, kalıcı olması yönüyle de konuşma ve dinlemeden farklılık göstermektedir (Aktepe, 2020).

Bahsi geçen yazma, öğretmenin söylediklerini öğrencinin defterine aynen geçirmesi değil, geleneksel olmayan yazmadır. Geleneksel yazma aktiviteleri; söylenenleri not alma, tahtadakileri deftere aynen geçirme, 
rapor hazırlama, aynı cümleleri alarak özet çıkarma ve öğretmen değerlendirme yazıları gibi etkinlik tiplerini içerirken geleneksel olmayan yazma aktiviteleri; günlük, mektup, broşür, şiir, kavram haritası, poster hazırlama, diyagram oluşturma, hikâye yazma ve şarkı gibi bir dizi etkinlik aracını içerir (Aydın, 2018; Koçak, 2013; Özyurt,2011; Uzoğlu, 2014). Homstad ve Thorson (1996) ise serbest yazma, kelime bahçesi, liste oluşturma, diyaloglar, betimleme, özetleme, akran değerlendirmeli yazılar, film/video ve etkileşimli bilgisayar kullanımı gibi yazma aktivitelerinin sınıf içerisinde ve eğitim sürecinde kullanılabileceğini ifade etmiştir.

Farklı yazma aktiviteleri sayesinde öğrenciler, eskiden öğrendiği bilgiler ile yeni öğrendikleri arasında bağlantı kurabilir (Erol, 2010). Farklı yazma aktiviteleri kullanmak, öğrencilerin yazmaya yönelik ilgilerini artırabilir (Aktepe, 2020). Fakat öğrencilerin değişik şekillerde öğrenmesi, yazmanın etkisini artırmada etkinlik seçimini önemli kılmaktadır. Hand ve Prain (2002); amaç, tür, muhatap, konu ve metin üretim metodu olmak üzere toplam beş bileşenin tanımlandığı ve yazma aktivitelerinin nasıl seçileceğiyle alakalı bir model oluşturmuşlardır. Yani öğrenme amaçlı yazma aktiviteleri kullanılırken niçin yazılacağı̆, ne ile yazılacağı, kime yazılacağı, ne yazılacağı ve nasıl yazılacağı iyi düşünülmelidir.

Oluşturulan modelin ana unsurlarından biri konudur. Yazmanın hangi konuda yapılacağı, yazma sürecinde öncelikli yapılması gereken hususlardandır. Modelin başka bir unsuru da amaçtır. Yazma etkinliğinin kullanılma zamanı yazmanın amacını şekillendirebilir. Yazma etkinlikleri; konu başında öğrencinin derse güdülenmesini sağlamak ve kavram yanılgılarını belirlemek, konu işlenirken derinlemesine bilgi sağlamak, konu bitiminde değerlendirme amaçlı ve kalıcı öğrenmeyi gerçekleştirmek için kullanılabilir. Diğer bir unsur, yazmanın kime yönelik olacağı̆, yani muhatabın belirlenmesidir. Yazmada kullanılacak dil, muhatap belirlendikten sonra okuyucuya göre düzenlenmelidir. Yazmanın nasıl yapılandırılacağıyla ilgili unsur olan metin üretim metodunda ise uygulama bireysel veya grupla gerçekleştirilebilir. Metin üretim metodu belirlendikten sonra yazı türü belirlenmelidir. Yazma etkinlikleri; broşür, hikâye, makale, gezi yazısı, 
dergi, kavram haritası, şiir, günlük, özet, mektup, diyagram, poster ve oyun yazısı gibi geleneksel olmayan aktiviteleri içerebilir.

Alanyazına bakıldığında belirtilen yazma aktivitelerinin birçok çeşidinin olduğu görülür. Araştırmalar incelendiğinde yazma türlerini belirlemeye ilişkin çalışmaların yetersiz olduğu ve net bir sınıflandırma oluşturmanın mümkün olmadığı ifade edilebilir. Yazma türleri, birçok araştırmacı tarafından içerik, etki alanları ve kullanış biçimi gibi farklı açılardan sınıflandırılmıştır (Tekin-Aytaş ve Uğurel, 2016). Özellikle Uğurel, Tekin ve Moralı'nın (2009) yazmaya ilişkin oluşturdukları sinıflandırma bu hususta oldukça önemlidir. Oluşturulan sınıflandırma ana hatlarıyla; iletişim amaçlı yazma, anlamlı yazma, günlük yazma, şiirsel yazma, teşvik edici yazma, bilgilendirici yazma, e-mail günlükleri, teşvik edici doğaçlama yazma, mektup yazma, matematiksel biyografiler, makale yazma, özetleyici yazma, ısındırıcı yazma, yeniden yazma, yansitıcı yazma, problem çözme, yaratıcı yazma, öğrenme kayıtları, resmi yazma ve resmi olmayan yazma şeklinde sıralanabilir.

Resmi yollarla kazanılabilen yazmanın; öğrenme aracı olarak kullanılma fikri, öğrencilerin bilgiyi somut ve fiziksel bir şekilde işledikleri ilkesine dayanır (Reaves, Flowers ve Jewell, 1993). Yazmanın öğrenmeye olan olumlu etkisi araştırmacılar tarafından ortaya konmuştur (Bozat ve Yıldız, 2015; Daşdemir, 2017; Daşdemir, 2018; Daşdemir, Cengiz, ve Uzoğlu, 2015; Günel, Kabataş-Memiş, ve Büyükkasap, 2009; Günel, Uzoğlu, ve Büyükkasap, 2009; Karaçağıl ve Avaroğulları, 2017; Uzoğlu, 2014; Uzoğlu ve Gürbüz, 2013; Yıldız ve Büyükkasap, 2011a; 2011b; 2011c).

Öğrenmeyle arasındaki ilişkilerin simetrik olmadığı ve öğrenmeye göre daha belirgin bir role sahip olan yazma (Klein and Boscolo, 2016), Emig tarafından ortaya atıldıktan sonra başta Amerika Birleşik Devletleri sonrada Avrupa ülkelerinde öğretim programlarına dahil edilmiştir (Daşdemir vd., 2015; Takaç, 2019). Türkiye'de öğrenme amaçlı yazma üzerinde durulmuş ve programların; öğrencilerin yaratıcılıklarını, yazılısözlü anlatım yetkinliklerini ve düşünme becerilerini geliştirebilecek şekilde düzenlenmesi kararı alınmıştır (17. Milli Eğitim Şurası, 2006). Ayrıca Fen Bilimleri Öğretim Programı́nda iletişim becerilerinin geliştirilebilmesi ve öğrenilenlerin kalıcı hale getirilebilmesi için öğrencilerin yazı yazmalarına imkan verilmesi gerektiği ifade edilmiştir 
(MEB, 2006). Fakat bazı araştırmacılara (Daşdemir vd., 2015) göre, öğrenme aracı olarak düşünülen yazmanın nerede ve nasıl kullanılacağının henüz belirtilmediği ve bunun araştırma sonuçları ile şekillenebileceği vurgulanmıştır. Bununla birlikte yurtdışında yapılan bir çalışmada (Kieft, Rijlaarsdam, and van den Bergh, 2006), Hollanda müfredatında yazmanın nasıl yapılacağına ilişkin bir yönergenin bulunmadığı ve öğrencileri motive etmenin üstünde durulmadığı ifade edilmiştir.

Öğrenme amaçlı yazma Erduran ve Akçay'a (2013) göre, geleneksel yazma etkinliklerinin yerine yapılandırmacı ve çağdaş yazma etkinliklerine odaklanıldığı bir yaklaşım iken; Takaç'a (2019) göre bir konu ya da kavramın öğretilmesi veya öğrenilmesi durumunda çeşitli yazma aktivitelerinin kullanılmasıdır. Özkan (2019) ise öğrenme amaçlı yazmayı, bireyin üstbilişsel faaliyetler yoluyla anlamlar üzerine oluşturdukları bir müzakere olarak tanımlamıştır. Bu doğrultuda öğrenme amaçlı yazmanın, bireylerin ilerleyebilmesi ve gelişebilmesi için önem arz ettiği ve değişik işlevlere hizmet ettiği düşünülebilir (Günel, Uzoğlu vd., 2009).

Her şeyden önce bireylerin kendileriyle alakalı fikir edinmelerine sebep olan yazma (Çontay, 2012), öğrencilerin düşünmelerine (Reaves vd., 1993) ve öğrenmeye eşsiz bir şekilde yardımcı olur (Emig. 1977). Yıldız'a (2016) göre yazma uygulamasına tabi olan öğrenci, kendisiyle baş başa kalarak var olan sorunu düşünür, becerilerini devreye sokar ve en önemlisi hiç kimsenin yardımına ihtiyaç duymadan zekâsını kullanmaya başlar. Öğrenme amaçlı yazma öğrencilerin, akıl yürütme becerilerini geliştirmekte (Akar, 2007); yazı yazmaya olan inançlarını artırmakta (Reaves vd., 1993); iletişim ve dil becerilerine sahip olmaları hususunda ve öğrenilenlerin pekiştirilmesinde onlara yardımcı olmakta (Ay, 2018; Yıldız ve Büyükkasap, 2011b); farklı disiplinlerde kullanılması gereken yazma türlerine alışmalarına katkıda bulunmakta (Yıldız ve Büyükkasap, 2011c) ve yorumlama, hatırlama becerilerini ilerletmektedir (Günel, Uzoğlu vd., 2009). Ayrıca yazma etkinlikleri, öğrencilerin; eskiden öğrendikleri ile yeni anlamlandırdıkları arasında ilişki kurmalarına yardım eder; içeriği sentezlemelerine ve çıarım yapmalarına olanak tanır; eleştirel düşünme becerilerini artırır (Bozat, 2014). Yazma insanın gelişmesine yardımcı olmanın yanı sıra toplumda 
empati kurabilme fırsatı da tanır (Tarikdaroğlu, 2019). Öğrenme amaçlı yazmanın faydaları fazla olmasına rağmen Türkiye'de, özellikle fen derslerinde bireysel olarak fazla zaman harcanması vakit kaybı olarak görüldügünden yazma etkinliklerine yeterince yer verilmemektedir (Daşdemir vd., 2015). Ayrıca yazma, yararlı bir yöntem olarak görülse de her çeşit yazma sonunda bir öğrenme gerçekleşmeyebilir (Sağırl1Özturan, 2010). Bu yüzden yazma etkinliklerinin öğrenmeyle sonuçlanabilmesi ve eğitim sürecinde aktif olarak kullanılabilmesi için bazı ön koşulların sağlanması gerekmektedir.

Yıldız'ın (2014) gerçekleştirdiği bir çalışmada, sınıf düzeyi veya yaşı büyük olan öğrencilerin küçük olan öğrencilere yazması; öğrencinin konuyla alakalı ön araştırma yapması; açık ve anlaşılır bir dil kullanılması; yazmadan önce bir aktivite örneğinin sunulması ve aktivite bitiminde öğrencilere puan verilmesi; yazılanın gözden geçirilmesi ve tekrar tekrar okunması gibi uygulama ve tedbirlerin öğrenme amaçlı yazmayı daha etkili hale getireceği iddia edilmektedir. Muhatabın çevresi, sınıf derecesi ve yaşı yazma etkinliğini gerçekleştiren öğrencinin daha açık, net ve anlaşılır bir dil kullanmasında etkin rol oynadığından yazma aktivitesinde bir muhatabın yani dinleyici ya da okuyucunun olması önemlidir (Yıldız, 2016). Yani öğrenciler, öğretmenlerinden başka bir kişiye yönelik yazılarını kaleme aldıklarında bir dizi dil transfer süreci yaşarlar (Yaman, 2018). Bunun yanı sıra öğrenme amaçlı yazmada, etkinlikler rutin hal almamalıdır. Etkinlikler değişik şekillerde hazırlanırsa hem derse yönelik ilgi hem de başarı artar (Öztürk, 2011). Sıralanan koşullara uyulması ve alınacak tedbirler, yazma aktivitelerinin daha etkin olmasını sağlayabileceği gibi öğrenme amaçlı yazma üzerine yapılan araştırmaların daha güvenilir ve geçerli sonuçlar vermesine katkıda bulunabilir.

Alanyazın incelendiğinde son yıllarda öğrenme amaçlı yazmaya yönelik araştırmaların arttığı gözlenmektedir. Gerçekleştirilen araştırmaların sonucunda, öğrenme amaçlı yazma aktivitelerinin öğrenmeye katkı sağladığını gösteren bulgular elde edilmiştir (Bozat ve Yıldız, 2015; Daşdemir, 2018; Günel, Kabataş-Memiş vd., 2009; Günel, Uzoğlu vd., 2009; Hand and Prain, 2002; Karaçağıl ve Avaroğulları, 2017; Kieft vd., 2006; Uzoğlu, 2014; Yıldız ve Büyükkasap, 2011a; 2011b; 2011c). Eğitimin her kademesinde gerçekleştirilen ön test-son test modelli 
deneysel araştırmaların genellikle benzerlik gösterdiği ve öğrenme amaçlı yazma etkinliğinin uygulandığı deney gruplarının kontrol gruplarına göre daha başarılı oldukları saptanmıştır. Aynı şekilde araştırmalara katılan deney grubu öğrencilerinin kendi düşüncelerini rahat bir şekilde ifade etmelerini sağlayan açık uçlu sorulara verdikleri göreceli cevaplar; unutulan konuların yeniden hatırlanmasında ve konunun tekrarlanmasında öğrenme amaçlı yazmanın etkili olduğunu göstermektedir. Ayrıca öğrenciler, yazma aktiviteleriyle konuları pekiştirdiklerini ve yazarak öğrendiklerini belirtmişlerdir (Bozat ve Yıldız, 2015; Günel, Uzoğlu vd., 2009; Koçak ve Seven, 2016; Yıldız ve Büyükkasap, 2011b). Fakat bazı çalışmalarda (Daşdemir, 2017; Daşdemir vd., 2015; Reaves vd., 1993) geleneksel yöntemlere nazaran öğrenme amaçlı yazma etkinliklerinin anlamlı bir fark oluşturamadığı tespit edilmiştir. Kısacası iyi bir ön hazırlık ve doğru yönlendirmeler, öğrenme amaçlı yazmanın hem doğrudan hem de dolaylı etkisini artırarak akademik başarıya pozitif yönde etki edebilir.

Ulusal alanyazın incelendiğinde öğrenme amaçlı yazma hakkında herhangi bir meta-sentez çalışmasına rastlanmamıştır. Araştırmada belirtilen kriterler ayrıntılı bir şekilde analiz edildiği için araştırmanın bu konu üzerine çalışma yapacaklara ışık tutması beklenmektedir. $\mathrm{Bu}$ araştırmanın; benzer değişken, örneklem ve yöntemlerle gerçekleştirilecek çalışmaların dışına çıkılmasına yardımcı olabileceği düşünülmektedir. Ayrıca bu eğilim birbirini tekrarlamayan ve yeni çalışmaların yapılmasıyla alanyazını zenginleştirecektir. İfade edilen gerekçe doğrultusunda aşağıda belirtilen sorulara yanıt aranmaya çalışılmıştır:

1. Tez ve makalelerin yıllara göre dağılımı nasıldır?

2. Tez ve makaleler, hangi üniversite ve enstitülerde gerçekleştirilmiştir?

3. Tez ve makalelerde hangi amaçlara ulaşılması hedeflenmiştir?

4. Tez ve makalelerde hangi yöntemler kullanılmıştır?

5. Tez ve makalelerde hangi konu alanları ele alınmıştır?

6. Tez ve makalelerde hangi örneklem kademeleri tercih edilmiştir?

7. Tez ve makalelerde hangi sınıf düzeyi tercih edilmiştir?

8. Tez ve makalelerin örneklem büyüklüklerine göre dağılımı nasıldır? 
9. Tez ve makalelerde hangi veri toplama araçları kullanılmıştır?

10. Tez ve makalelerin uygulama sürelerine göre dağılımı nasıldır?

11. Tez ve makalelerde hangi istatistiksel analiz yöntemleri kullanılmıştır?

12. Tez ve makalelerin doküman türlerine göre dağılımı nasıldır?

13. Tez ve makalelerin çalışma yerlerine göre dağılımı nasıldır?

14. Tez ve makalelerin çalışma bölgelerine göre dağılımı nasıldır?

15. Tez ve makalelerde ne tür sonuçlara ulaşılmıştır?

16. Tez ve makalelerde kullanılan kaynak sayılarına göre dağılım nasıldır?

\section{Araștırmanın Amacı}

Çalışmanın amacı, Türkiye'de öğrenme amaçlı yazma ile ilgili yapılmış araştırmaları meta-sentez yöntemi ile analiz ederek belirlenen kriterlere göre nasıl bir dağılım gösterdiğini saptamaktır.

\section{Araştırmanın Sınırlılıkları}

Çalışma, alanyazın taraması sonucunda kapsama dâhil edilen, 2020 yılının sonuna kadar yayınlanan ve erişim izni olan 45 tez, 22 TR dizin tabanlı makale olmak üzere toplam 67 araştırma ile sınırlıdır. İncelenen araştırmalar, çalışmaya dâhil edilirken öğrenme amaçlı yazma sürecinin eğitim ortamlarında kullanılması ve anlama-öğrenme ile ilgili olması temel alınmıştır. Araştırmaların başlıklarında, "öğrenme amaçlı yazma, çoklu yazma etkinlikleri, yaparak yazarak bilim öğrenme, yazma etkinlikleri ve yazma aktiviteleri" gibi kelimelerin kullanılmasına rağmen yazma becerisi ile ders kitaplarındaki yazma etkinlikleri üzerine gerçekleştirilen araştırmalar, amaca uygun olmadığından ve farklı boyutları barındırdığından çalışma kapsamına dâhil edilmemiştir. 


\section{Yöntem}

\section{Araştırmanın Deseni}

$\mathrm{Bu}$ araştırma, tematik içerik analizi yani bir meta-sentez çalışmasıdır. Meta-sentez çalışmaları, belirli bir alanda gerçekleştirilen araştırmaların nitel bulgularının; yorumlanmasını, benzer ve farklılıklarının ortaya çıkarılmasını, değerlendirilmesini ve yeni çıkarımlar yapılmasını amaçlayan yöntemdir (Polat ve Ay, 2016). Ayrıca meta-sentez çalışmaları belirli bir alanda gerçekleştirilmiş nitel araştırmaların yine nitel bir anlayışla ele alınarak, benzerlik ve farklılıkların karşılaştırmalı olarak ortaya konmasını içermektedir (Çalık ve Sözbilir, 2014). İncelenen araştırmaların genelinde nicel veya nitel araştırma yöntemleri kullanıldığı için çalışmaların meta-senteze uygun olduğu görülmüştür. Bu çalışmada, Türkiye'de yürütülen ve öğrenme amaçlı yazma hakkında 2008'den 2020 yılının sonuna kadar gerçekleştirilmiş olan 45 tez ve 22 makale araştırmacılar tarafından analiz edilmiştir.

\section{Verilerin Toplanması}

Akademik yayın türleri olarak makale ve lisansüstü tezler araştırma kapsamına alınmıştır. Çalışmada tarama için “öğrenme amaçlı yazma, yazmanın öğrenme amaçlı kullanımı, yazarak öğrenme, öğrenme aracı olarak yazma, yaparak yazarak bilim öğrenme, çoklu yazma etkinlikleri, yazma aktiviteleri, yazma etkinlikleri ve öğrenme yazıları" gibi anahtar kelimeler kullanılmıştır.

Çalışma kapsamına alınan tez ve makaleler için aşağıda sıralanan seçim ölçütleri kullanılmıştır:

- Araştırmanın Yüksek Öğretim Kurumu Ulusal Tez Merkezi ya da Ulakbim'de (TR Dizin) yayımlanmış olması.

- Başlığının "öğrenme amaçlı yazma", "yaparak yazarak bilim öğrenme", "çoklu yazma etkinlikleri", "yazma aktiviteleri", "yazma etkinlikleri”, “öğrenme yazıları”, "öğrenme aracı olarak yazma" ve "yazmanın öğrenme amaçlı kullanımı" anahtar kelimelerinden birini içermesi.

- Araştırmaların eğitim alanında yapılmış olması. 
- Tam metne ulaşılır olması ya da erişime açık olması.

- Araştırma verilerinin öğrenci, öğretmen adayı ya da öğretmenlerden alınmış olması.

- Araştırmaların Türkçe yazılmış olması.

- Araştırmada amaç, yöntem, örneklem, veri toplama araçları, istatistiksel analiz, bulgu ve sonuçların açık, net ve anlaşlır bir şekilde yazılmış olması.

- Araştırmanin tez veya makale olması.

- Farklı anahtar kelimelerin bir başlık altında birlikte kullanıldığ araştırmaların çalışmaya yalnızca bir defa dâhil edilmesi.

Yapılan tarama neticesinde ulaşılan yayınların, özet kısımları araştırmacılar tarafından dikkatli okunarak dâhil etme ölçütlerine uygun olmayan yayınlar analiz dışı bırakılmıştır. Yayınlanan tez ve makalelerin özet kısımları karar vermek için yeterli görülmediği durumlarda metnin tamamı araştırmacılar tarafından detaylı şekilde incelenmiştir. Tarama sonucunda 01.01.2021 tarihine kadar 98 tez, 127 hakemli dergide yayımlanmış makale olmak üzere toplam 225 yayına ulaşılmıştır. Türkçe ve amaca uygun olmayan, yazma becerisini ölçen ve ders kitaplarındaki yazma etkinliklerinin değerlendirilmesini amaçlayan araştırmalar kapsam dışı bırakılmış, eğitim ve öğrenme alanı ile ilgili olan araştırmalar çalışmaya dâhil edilmiştir. Yüksek Öğretim Kurumu Ulusal Tez Merkezi ve Ulakbim'de yapılan tarama sonucu ulaşılan ve çalışmaya dâhil edilen tez ve makalelerin anahtar kelimelere göre dağılımı Tablo 1 'de verilmiştir.

Tablo 1. Tarama sonucu ulaşılan ve çalışma kapsamına alınan araştırma sayısı

\begin{tabular}{lllll}
\hline Anahtar Kelimeler & \multicolumn{2}{l}{$\begin{array}{l}\text { Yüksek Öğretim Kurumu } \\
\text { Ulusal Tez Merkezi }\end{array}$} & \multicolumn{2}{l}{ Ulakbim TR Dizin } \\
\cline { 2 - 5 } & $\begin{array}{l}\text { Ulaşılan } \\
\text { Tez }\end{array}$ & $\begin{array}{l}\text { Çalışmaya } \\
\text { Dâhil Edilen } \\
\text { Tez Sayısı }\end{array}$ & $\begin{array}{l}\text { Ulaşılan } \\
\text { Makale } \\
\text { Sayısı }\end{array}$ & $\begin{array}{l}\text { Çalışmaya Dâhil } \\
\text { Edilen Makale } \\
\text { Sayısı }\end{array}$ \\
\hline Öğrenme Amaçlı Yazma & 24 & 24 & 33 & 11 \\
Yaparak Yazarak Bilim Öğrenme & 4 & 2 & 3 & 3 \\
Çoklu Yazma Etkinlikleri & 5 & 5 & 1 & 1 \\
Yazma Aktiviteleri & 13 & 4 & 2 & 2 \\
Yazma Etkinlikleri & 52 & 10 & 88 & 5 \\
Toplam & $\mathbf{9 8}$ & $\mathbf{4 5}$ & $\mathbf{1 2 7}$ & $\mathbf{2 2}$ \\
\hline
\end{tabular}




\section{Kodlama Süreci}

Öncelikle çalışma kapsamına alınan her bir dokümanın kategorilerle alakalı bölümleri detaylı bir şekilde okunmuş ve elde edilen veriler bilgisayar ortamına aktarılmıştır. Araştırmacılar tarafından 67 çalışma kodlanmış, kodlamalar arasındaki tutarlılık kontrol edilmiştir. Akabinde çalışma kapsamına alınan tüm dokümanlar düşünülen ana kategoriler açısından incelenerek kodlanmıştır. Ayrıca veri çokluğu ve karmaşasının önüne geçmek için incelenen her bir doküman A1, A2, A3, ... A67 şeklinde kodlanmış ve çalışmada bu kodlar kullanılmıştır. Tüm kodlamalar kontrollü olarak üç aşamada tamamlanmıştır. Birinci aşamada tüm çalışmalar kategoriler göz önünde bulundurularak kodlamıştır. İkinci aşamada oluşturulan kodlar, tekrar kontrol edilerek düzenlenmiştir. Son aşamada kodların, birbirleri ile ilişkileri dikkate alınarak sınıflandırma işlemi tamamlanmıştır. Çalışmaya dâhil edilen tüm dokümanların kodlama işlemi tamamlandıktan sonra ana ve alt kategorilere ilişkin frekans-yüzde değerleri oluşturulmuştur.

\section{Verilerin Analizi}

Dokümanlar kapsamlı bir içerik analizine tabi tutulmuştur. Sosyal bilimler alanında sıklıkla kullanılan içerik analizi, belli kodlamalarla bir metnin bazı sözcüklerinin daha küçük içerik kategorileri ile özetlendiği, yinelenebilir ve sistematik bir analiz yöntemidir (Büyüköztürk, KılıçÇakmak, Akgün, Karadeniz ve Demirel, 2015). Bu araştırmada dokümanlar içerik analizine tabi tutulurken belli aşamalardan geçilmiştir. Araştırmaya dâhil edilen yayınlara erişim sağlandıktan sonra ilk olarak araştırmalar ana ölçütler açısından kategorize edilmiştir. Bu çerçevede çalışmaya dâhil edilen araştırmaların toplu bir özet halinde sunulabilmesi için bir tablo hazırlanmıştır. Daha sonra incelenen her bir yayın; yıl, amaç, üniversite ve enstitü, yöntem, konu alanı, örneklem kademesi, sınıf düzeyi, örneklem büyüklüğü, veri toplama aracı, uygulama süresi, istatiksel analiz, ulaşılan dokümanın türü, çalışma yeri, çalışma bölgesi, sonuç ve kaynak sayısına göre sınıflandırılmıştır.

Araştırma kapsaminda incelenen tez ve makaleler amacına uygun şekilde tablo ve grafikler halinde sunulmuştur. Verilerin bu şekilde 
sunulmasının temel nedeni; görselliği artırmak ve incelenen araştırmalar hakkında ilk bakışta fikir sahibi olma imkânı sağlamaktır. Tablo ve grafiklerde istatistiksel olarak sadece frekans ve yüzdelere yer verilmiştir. Ayrıca her bir tablo ve grafiğin altında genel bir açıklama yapıldıktan sonra araştırmalarda dikkat çeken kısımlar önem derecesine göre açıklanmıştır.

İçerik analizi sonucunda elde edilen frekans ve yüzde değerleri dokümanların analizi sırasında oluşturulan sinıflamalara yönelik karşılaştırmaların yapılmasına olanak tanımaktadır. Aynı zamanda sayısal değerler, araştırmanın tekrar edilmesi durumunda benzer sonuçlara ulaşılıp ulaşılmadığının ortaya çıkarılması bakımından önemlidir.

\section{Araştırmanın geçerlilik ve güvenirliği}

Kodlama esnasında herhangi bir hata oluşmaması için araştırmalar YÖK Ulusal Tez Merkezi ve Ulakbim veri tabanından indirildikten sonra üç ay boyunca incelenmiştir. Daha sonra araştırma soruları doğrultusunda ilgili tablo oluşturulmuş ve kodlamalar yapılmıştır. Kodlamaların güvenilir olması için iki hafta boyunca ana kategoriler doğrultusunda analizler tekrar gözden geçirilmiş ve kodlamaların büyük oranda tutarlı olduğu görülmüştür. Ayrıca kodlamalar tamamlandıktan sonra alanında uzman bir öğretim üyesinin görüşüne başvurularak gerekli düzeltmeler yapılmıştır. Çalışmanın geçerlilik ve güvenirliği için belirlenen 9 tez, 4 makale toplam 13 yayın (çalışmaların yaklaşık \%20'si) bir uzman tarafından incelenerek tekrar kodlanmıştır. Araştırmacılar ve uzmanın yapmış oldukları kodlamanın birbiriyle olan uyumu ve güvenirlik durumu Miles ve Huberman'ın (1994) önerdiği araştırmacılar arası uyuşum hesaplama formülüyle hesaplanmıştır (akt. Baynazoğlu ve Atasoy, 2020).

$$
\text { Güvenirlik }=\left[\frac{\text { Görüş Birliği }}{\text { Görüş Birliği }+ \text { Görüş ayrılı̆̆ı }}\right] \times 100
$$

Yukarıda verilen formülle yapılan işlem neticesinde araştırmacıların yaptığı kodlamalardaki uyumun \%90'ın üzerinde olması, yapılan kodlamanın güvenilir olduğunu gösterir (Miles ve Huberman, 1994'ten 
akt. Baynazoğlu ve Atasoy, 2020). Bu araştırma için araştırmacılar ve uzman tarafından yapılan kodlama uyuşum değeri \%96,2 olarak tespit edilmiştir. Bulunan bu uyuşum değeri, araştırmaya ait verilen kodlama işleminin güvenilir olduğunu göstermektedir.

\section{Bulgular}

\section{Öğrenme Amaçlı Yazma Araştırmalarının Yıllara Göre Dağılımı}

Çalışmada incelenen tez ve makalelerin yayın tarihleri göz önünde bulundurulduğunda 2008-2020 yılları arasında çubuk grafikteki gibi bir dağılım gösterdikleri söylenebilir.

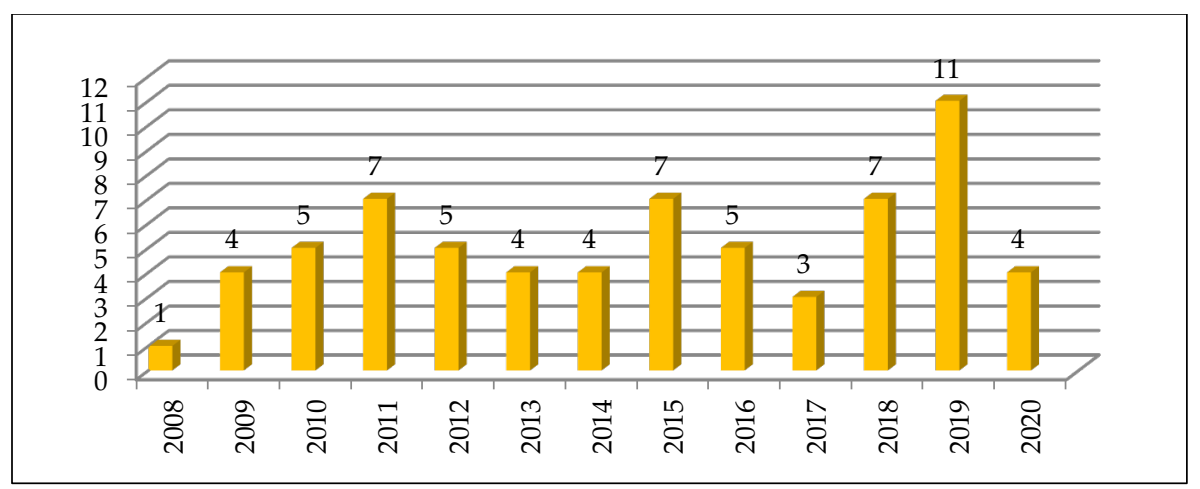

Grafik 1. Araştırmaların Yıllara Göre Dağılımı

Grafik 1 incelendiğinde, çalışma kapsamına dahil edilen 45 tez ve 22 makale olmak üzere toplam 67 yayının en fazla 2019 yılında, en az ise 2008 yılında tamamlandığı görülmektedir. Dünyada 1977 yılında temelleri Emig tarafından atılan öğrenme amaçlı yazmanın eğitim programlarına kazandırılması başta Amerika Birleşik Devletleri sonra da onu takiben Avrupa ülkelerinde gerçekleşmiştir. Türkiye'de ise 20052006 eğitim-öğretim yılında ilköğretim seviyelerinde köklü bir değişim gerçekleşmiş ve bu değişimle birlikte bilginin oluşturulmasında bireyin aktif olmasını temel alan yapılandırmacı yaklaşım etkili olmuştur. Türkiye'de ilk defa öğrenme amaçlı yazma ile ilgili bir yayının 2008 yılında tamamlanması, öğretim programındaki iyileştirmelerin bir sonucu olabilir. 
Bilginin yapılandırmasına yardımcı olan ve anlaşılmasını kolaylaştıran öğrenme amaçlı yazma, eğitim programındaki köklü değişimden üç yıl sonra araştırmacıların dikkatini çekmeye başlamıştır. $\mathrm{Bu}$ sayede yıllar ilerledikçe gerçekleştirilen araştırmaların sayısında bir artış görülmüştür. 2020 yılında tamamlanan araştırma sayısının az olmasının nedenlerinden biri salgın döneminde okulların uzun süre kapalı kalması olarak düşünülebilir.

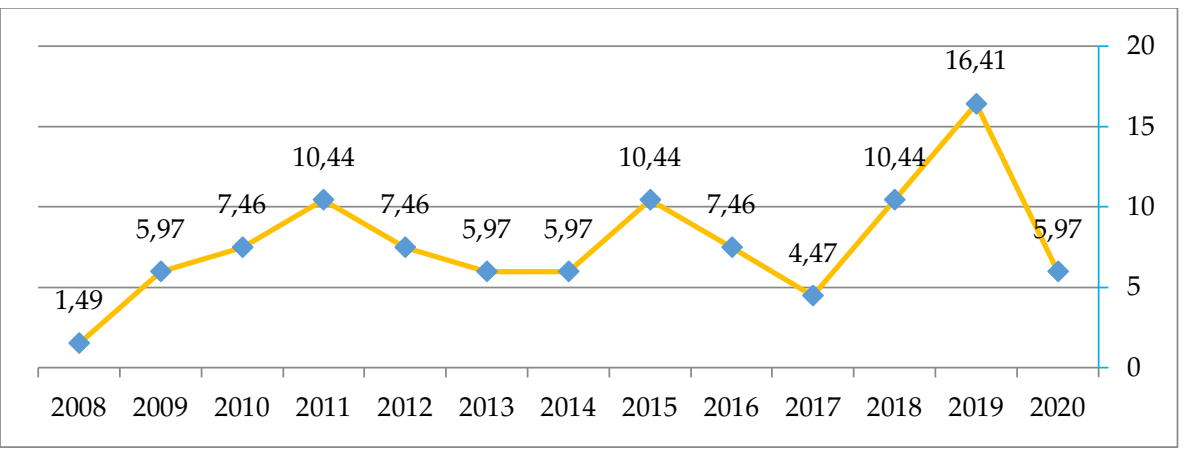

Grafik 2. Araştırmalarnn Yıllara Yüzdelik Dilimleri

Çalışmaya dâhil edilen araştırmaların; yüzde 16,4'ü 2019 yılında, yüzde 10,4'ü 2018 yılında yapılmıştır. 2011 ve 2015 yıllarında tüm yayınlar içerisinde yüzde 10,4'lük bir oran saptanmıştır. 2010, 2012 ve 2016 yıllarında ise yüzde 7,5'lik bir oran göze çarpmaktadır. Ayrıca araştırmaların; yüzde 6'sı 2009, 2013, 2014 ve 2020 yıllarında, yüzde 4,5'i 2017 yılında ve yüzde 1,5'i 2008 yılında tamamlanmıştır.

\section{Öğrenme Amaçlı Yazma İle Ilgili Yapılan Tezlerin Üniversite ve Enstitülere Göre Dağılım}

Çalışmada incelenen tezlerin, üniversite ve enstitülere göre dağılımı dikkate alındığında Atatürk Üniversitesi ve Eğitim Bilimleri Enstitüleri'nde tamamlanan lisansüstü tezlerin diğer üniversite ve enstitülere göre daha fazla sayıda oldukları ifade edilebilir. Tezlerin üniversite ve enstitülere göre dağglımı Tablo 2' de sunulmuş̧tur.

Tablo 2'de çalışma kapsamında incelenen 45 lisansüstü tezin hazırlandığı üniversite ve enstitüye göre dağılımı verilmiştir. Tezlerin 
üniversitelere göre dağılımı incelendiğinde, 19 farklı üniversitede hazırlandıkları görülmektedir. Üniversitelerin sınıflandırılmasında ikiden daha az sayıda tez hazırlanan üniversiteler "diğer" başlı̆̆ı altında sunulurken iki ve daha fazla sayıda tez hazırlanan üniversiteler isimleriyle verilmiştir.

Tablo 2'de öğrenme amaçlı yazmayla ilgili tamamlanan lisansüstü tezlerin üniversitelere göre dağılımına bakıldığında en fazla Atatürk Üniversitesi'nde $16(\% 35,6)$ lisansüstü tez hazırlanmıştır. İkinci sırada 4 adet $(\% 8,9)$ ile Marmara Üniversitesi; üçüncü sırada 3 adet $(\% 6,7)$ ile Pamukkale Üniversitesi, Gazi Üniversitesi ve Binali Yıldırım Üniversitesi; dördüncü sırada ise 2 adet $(\% 4,4)$ ile Dokuz Eylül Üniversitesi ve Giresun Üniversitesi yer almaktadır.

Lisansüstü tezlerin enstitülere göre dağılımına bakıldığında eğitim bilimleri enstitülerinde 26 (\%57,8); fen bilimleri enstitülerinde 13 (\%28,9) ve sosyal bilimler enstitülerinde $6(\% 13,3)$ lisansüstü tez tamamlanmıştır. On iki üniversitede ise sadece birer adet lisansüstü tezin tamamlandığ 1 görülmektedir.

Tablo 2. Tezlerin üniversite ve enstitülere göre dağılımı

\begin{tabular}{llllll}
\hline \multirow{2}{*}{ Üniversite } & \multicolumn{2}{l}{ Enstitüler } & & \multicolumn{2}{c}{ Toplam } \\
\cline { 2 - 6 } & $\begin{array}{l}\text { Eğitim } \\
\text { Bilimleri } \\
\text { Enstitüsü }\end{array}$ & $\begin{array}{l}\text { Fen } \\
\text { Bilimleri } \\
\text { Enstitüsü }\end{array}$ & $\begin{array}{l}\text { Sosyal } \\
\text { Bilimler } \\
\text { Enstitüsü }\end{array}$ & $f$ & $\%$ \\
\hline Atatürk Üniversitesi & 12 & 4 & 0 & 16 & 35,6 \\
Marmara Üniversitesi & 4 & 0 & 0 & 4 & 8,9 \\
Pamukkale Üniversitesi & 1 & 1 & 1 & 3 & 6,7 \\
Gazi Üniversitesi & 3 & 0 & 0 & 3 & 6,7 \\
Binali Yıldırım Üniversitesi & 0 & 1 & 2 & 3 & 6,7 \\
Dokuz Eylül Üniversitesi & 2 & 0 & 0 & 2 & 4,4 \\
Giresun Üniversitesi & 0 & 2 & 0 & 2 & 4,4 \\
Diğer & 4 & 5 & 3 & 12 & 26,7 \\
Toplam & $26(\% 57,8)$ & $13(\% 28,9)$ & $6(\% 13,3)$ & 45 & $\% 100$ \\
\hline
\end{tabular}

\section{Öğrenme Amaçlı Yazma Araştırmalarının Amaçlarına Göre Dağılımı}

Çalışmada incelenen tez ve makalelerin amaçları doğrultusunda dört tema oluşturulmuştur. Bu temalar: konuya ve derse yönelik, beceriye yönelik, değerlendirmeye yönelik ve diğerleridir. Araştırmaların amaçlarına ait bulgular Tablo 3'te verilmiştir. 
Tablo 3. Incelenen tezlerin amaçları

\begin{tabular}{llll}
\hline Tema & Alt Tema & $f$ & $\%$ \\
\hline & Akademik Başarı & 42 & 32,0 \\
& Tutum & 24 & 18,3 \\
& Öğrenme ve Anlama & 17 & 13,0 \\
& Bilginin Kalıcılı̆̆ı & 6 & 4,6 \\
Konuya ve & Kavram Yanılgıları & 2 & 1,5 \\
Derse Yönelik & Güdülenme & 1 & 0,8 \\
& Motivasyon & 1 & 0,8 \\
& Hatırlama & 1 & 0,8 \\
& Farkındalık & 1 & 0,8 \\
& Uygulama Düzeyi & 1 & 0,8 \\
& Kavrama & 1 & 0,8 \\
& Kaygı & 1 & 0,8 \\
\hline \multirow{5}{*}{ Beceriye Yönelik } & Bilimsel Süreç Becerileri & 6 & 4,6 \\
& Öz yeterlik & 3 & 2,3 \\
& Üst Biliş/ Biliş Üstü Beceri & 3 & 2,3 \\
& Eleştirel Düşünme Becerisi & 2 & 1,5 \\
Değerlendirmeye Yönelik & Problem Çözme Becerisi & 1 & 0,8 \\
\hline & Görüş & 12 & 9,2 \\
& Yazmanın Etkili Kullanımı & 1 & 0,8 \\
& Yazmaya Dair Öğretimin Değerlendirilmesi & 1 & 0,8 \\
\hline \multirow{5}{*}{ Diğer } & Ölçme Aracı Geliştirme & 1 & 0,8 \\
& Alan Öğretimi Bilgi ve Beceri Düzeyi & 1 & 0,8 \\
\hline Toplam & Epistemolojik İnanç & 1 & 0,8 \\
\hline & Bilişsel Yapı & 1 & 0,8 \\
\hline & & $\mathbf{1 3 1}$ & $\mathbf{1 0 0}$ \\
\hline
\end{tabular}

Çalışmaya dâhil edilen 67 araştırmanın 28'inde birer, 39'unda birden fazla olmak üzere toplam 131 amaca yer verilmiştir. Tablo 3 incelendiğinde, birinci temanın alt temalarında, öğrenme amaçlı yazma etkinliklerinin uygulandığı ünite ve konuların; başarı, tutum, öğrenme, kalıcılık, güdülenme, kavrama, anlama, farkındalık ve hatırlama gibi değişkenlere etki etmeyi hedeflediği görülmektedir. Ayrıca uygulanan ünite ve konularda derse yönelik kaygının, motivasyonun, uygulama düzeylerinin ve kavram yanılgılarının hangi düzeyde olduğunu araştırmak, yayınların amaçları arasında yer almaktadır. Konuya veya derse yönelik olarak gerçekleştirilen bu amaçların, özellikle öğrencilerin akademik başarıları $(n=42)$, tutumları $(n=24)$ ve öğrenmelerinin belirlenmesi ( $n=17)$ üzerine yapıldığı söylenebilir. Benzer şekilde bilginin kalıcılığına yönelik anlamlı farklılığın belirlenmeye çalışıldığı araştırmalar $(n=6)$ azımsanmayacak ölçüdedir. Akademik başarı, tüm 
araştırmalar içerisinde yüzde 32'lik bir dilimle en fazla kullanılan değişkenken, yüzde 18,3 ile tutum ikinci, yüzde 13 ile öğrenme üçüncü sırada yer alan değişkenlerdir.

Beceriye yönelik tema incelendiğinde, araştırmalarda ölçülmesi amaçlanan birçok becerinin olduğu göze çarpmaktadır. En fazla bilimsel süreç becerilerinin $(n=6)$ daha sonra öz yeterlik ve biliş üstü becerilerin $(n=3)$ değişimleri belirlenmeye çalışılmıştır. Eleştirel düşünme becerisi $(n=2)$ ve problem çözme becerisi $(n=1)$ çalışmaya dâhil edilen araştırmalarda en az kullanılan alt temalar olarak saptanmıştır.

Değerlendirmeye yönelik temada, genellikle öğrenci ve öğretmen görüşlerinin belirlenmeye $(n=12)$ çalışıldığ ifade edilebilir. Yazmanın etkili kullanımı ve yazmaya dair öğretimin değerlendirilmesi araştırmalarda birer kez ele alınan amaçlardır.

$\mathrm{Bu}$ üç temanın dışında kalan amaçlar "diğer" başlığı altında sinıflandırılmıştır. Sınıflandırma sonucunda; ölçme aracı geliştirme, alan öğretimi bilgi ve beceri düzeyi, epistemolojik inanç ve bilişsel yapı, araştırmalarda amaçlanan ve birer defa kullanılan değişkenlerdir.

\section{Öğrenme Amaçlı Yazma Araştırmalarının Yöntemlerine Göre Dağılımı}

Çalışmada incelenen tez ve makalelerin yöntemleri dikkate alındığında çoklu ve nicel çalışmaların nitel çalışmalara göre daha fazla yapıldığ 1 ifade edilebilir. Araştırmaların yöntemlerine göre dağılımı Grafik 3'te verilmiştir.

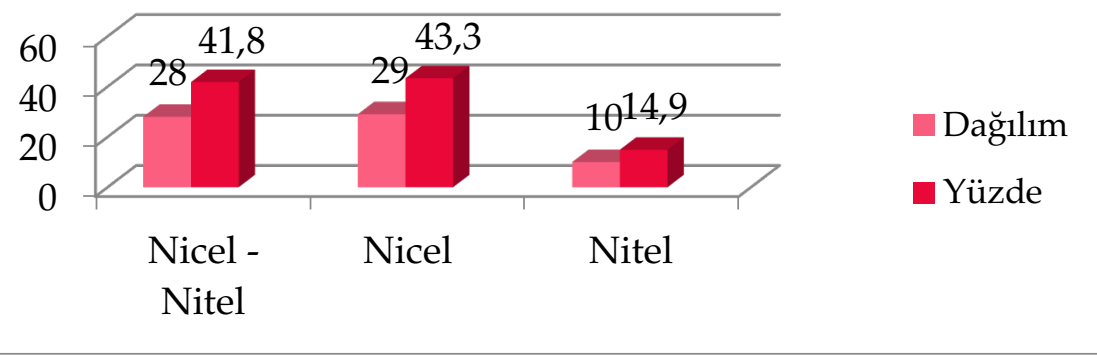

Grafik 3. Incelenen Araştırmaların Yöntemlerine Göre Dă̆ılım ve Yüzdeleri 
Araştırmalarda kullanılan yöntemlere yönelik veriler incelendiğinde; öğrenme amaçlı yazmanın etkisinin belirlenmeye çalışıldığı deneysel çalışmaların çok fazla olduğu görülmektedir. Özellikle son yıllarda gerçekleştirilen araştırmalarla öğrenme amaçlı yazma süreci derinlemesine değerlendirilmeye çalışılmıştır. Ayrıca araştırmalarda kullanılan yöntemler genellikle deneysel olmasına karşın bu araştırmalardan 28 tanesi nitel verilerle desteklenmiş çoklu yöntem araştırmalarıdır. Nitel yöntemle yürütülen araştırma sayısının ise nicel ve çoklu yöntemlerle yürütülen çalışmaların yarısından az olduğu $(\mathrm{f}=10)$ görülmektedir. Bu veriler, Türkiye'deki alanyazında öğrenme amaçlı yazma üzerine yapılan araştırmaların yarısına yakınının nicel ve çoklu yöntemler doğrultusunda yürütüldüğünü göstermektedir. Çalışmaya dahil edilen araştırmaların; yüzde 43,3'ü nicel yöntemle, yüzde 41,8'i çoklu yöntemle ve yüzde $14,9^{\prime} u$ nitel yöntemle yapılmıştır. Yöntemlerdeki bu farklılıkların yeni yapılacak araştırmaların planlamasına yardımcı olacağı düşünülmektedir.

\section{Öğrenme Amaçlı Yazma Araştırmalarının Konu Alanlarına Göre Dağılımı}

Çalışmada incelenen tez ve makalelerin konu alanları dikkate alındığında fen alanlarında daha çok çalışma yapıldığı görülmektedir. Araştırmaların konu alanlarına göre dağılımı Grafik 4'te sunulmaktadır.

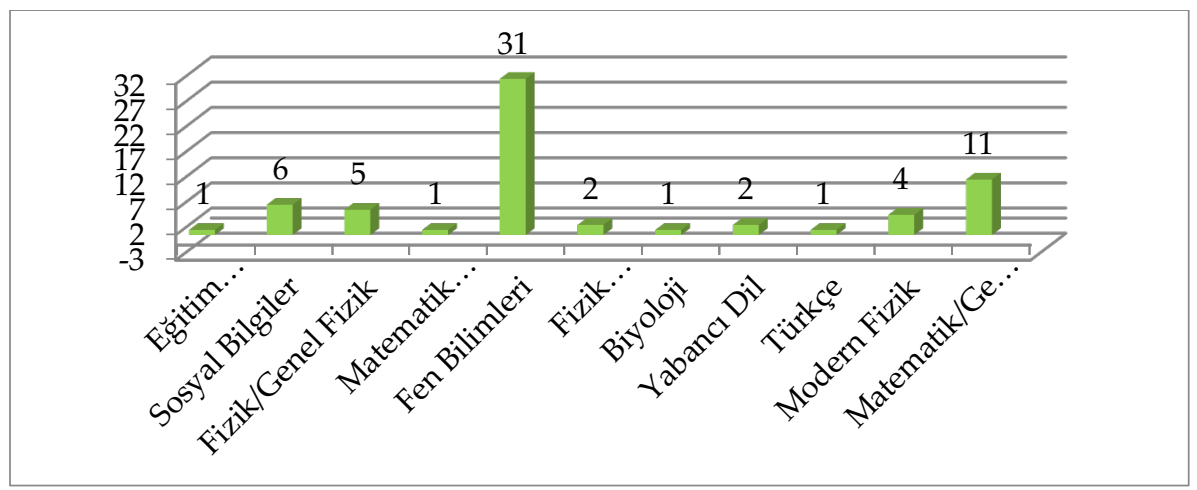

Grafik 4. Araştırmalarda Ele Alınan Konu Alanları 
Çalışmalar incelendiğinde; 65 çalışmada ele alınan konu alanının belirtildiği fakat 2 çalışmada nitel araştırma yöntemlerinden doküman incelemesi kullanıldığından (A5 ve A12) herhangi bir konu alanı üzerinde durulmadığ1 görülmüştür. Grafik 4 incelendiğinde, çalışmalarda ele alınan konuların daha fazla fen alanlarında olduğu görülmektedir.

Öğrenme amaçlı yazma, bir konuyu daha iyi anlamak ve yapılandırmak için öğrencinin bilgiyi beyin süzgecinden geçirerek yazıya aktardığı bir süreçtir. Doğası gereği soyut ifadeler barındıran fen derslerini somut ve anlaşlır hale getiren bu yapılandırma işlemi, uygulamaların çoğunun fen bilimleri alanında gerçekleştirilmesini açıklayabilir. Çalışma kapsamında çoğunlukla fen bilimleri ve matematik alanlarında kullanılan öğrenme amaçlı yazma, sosyal bilimler alanında ilk olarak 2010 yılında eğitim psikolojisi dersinde (A65) gerçekleştirilmiştir. Türkçe derslerinde ise yazma etkinlikleri fazla kullanılmasına rağmen genellikle çalışmalar, yazma becerisini ölçmeye ve geliştirmeye yönelik olduğundan araştırma kapsamına alınmamış ve bu yüzden en az kullanılan alanlardan biri olarak saptanmıştır. Ayrıca incelenen 65 araştırma içerisinde, yalnızca 11 konu alanına odaklanılması öğrenme amaçlı yazmanın diğer alanlardaki eksikliklerini ortaya koymaktadır.

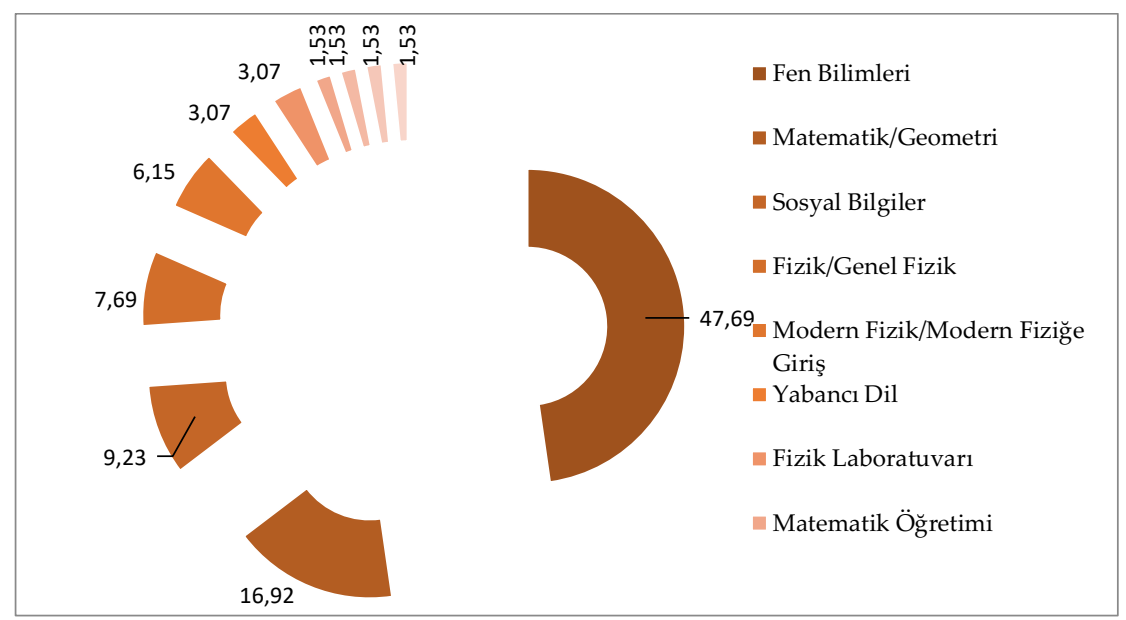

Grafik 5. Araştırmalarda Ele Alınan Konu Alanlarının Yüzdelik Dilimleri 
Öğrenme aracı olarak yazmanın kullanıldığı bu yayınların yüzde 47,7'si fen bilimleri, yüzde 16,9'u matematik/geometri konuları hakkındadır. Çalışmalarda en az kullanılan Türkçe, Biyoloji, Eğitim Psikolojisi ve Matematik Öğretimi alanlarının oranının 1,5 olduğu ifade edilebilir. Araştırmada ele alınan konu alanlarının yüzdelik dilimleri Grafik 5'te sunulmaktadır.

\section{Öğrenme Amaçlı Yazma Araştırmalarında Çalışma Gruplarının Kademelere Göre Dağılımı}

Çalışmada incelenen tez ve makalelerin örneklem kademeleri dikkate alındığında ortaokulda yapılan çalışmaların diğer kademelere göre daha fazla olduğu söylenebilir. Araştırmaların örneklem kademelerine göre dağılımı Grafik 6'da sunulmaktadır.

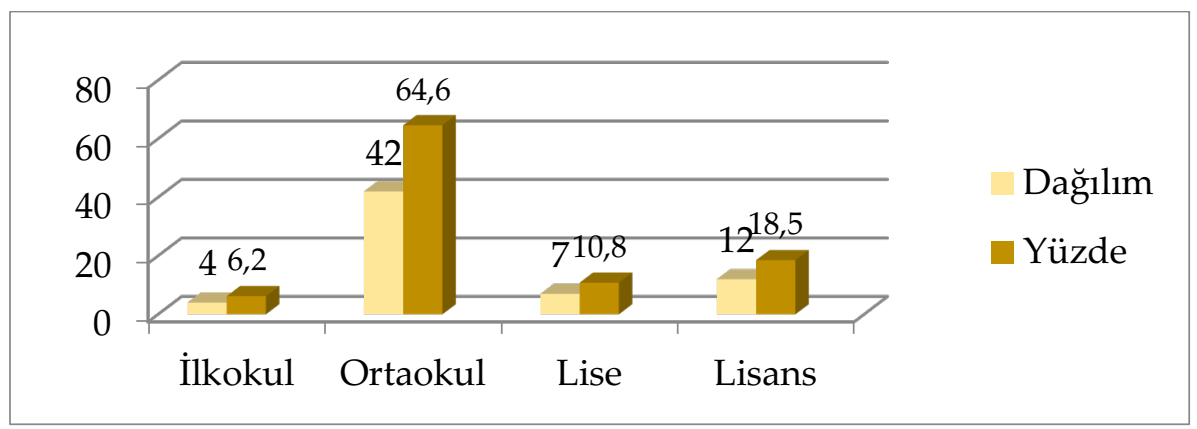

Grafik 6. Araștırmaların Örneklem Kademelerine Göre Dağılım ve Yüzdeleri

Çalışma kapsamında incelenen araştırmaların 65'inde örneklem kademesi belirtilmiş fakat 2 araştırmada nitel araştırma yöntemlerinden doküman incelemesini kullandığından (A5 ve A12) herhangi bir örneklem kademesi belirtilmemiştir. Çalışma kapsamında incelenen araştırmaların $39^{\prime} \mathrm{u}$ ortaokul öğrencileriyle, $3^{\prime} \ddot{u}$ ortaokul fen bilimleri öğretmenleriyle, 12'si lisans öğrencileriyle yürütülmüştür. Ayrıca araştırmaların 7 'si lise öğrencilerinin katılımıyla, $4^{\prime}$ ü ise ilkokul öğrencilerinin katılımıyla gerçekleştirilmiştir. Araştırmalardaki örneklem kademelerinin tüm yayınlar içerisindeki yüzdelerine bakıldığında 
ortaokul öğrencileriyle tamamlanan araştırmaların yüzde 60; ortaokul fen bilimleri öğretmenleriyle tamamlanan araştırmaların yüzde 4,6; lisans öğrencileriyle tamamlanan araştırmaların yüzde 18,5; lise öğrencileriyle tamamlanan araştırmaların yüzde 10,8 ve ilkokul öğrencileriyle tamamlanan araştırmaların yüzde 6,2 olduğu bulunmuştur.

\section{Öğrenme Amaçlı Yazma Araştırmalarının Sınıf Düzeylerine Göre Dağılımı}

Çalışmada incelenen tez ve makalelerin sınıf düzeyleri dikkate alındığında ortaokul öğrencileriyle yürütülen çalışmaların diğer seviyelerdeki öğrencilerle yürütülen çalışmalara göre daha fazla olduğu söylenebilir. Araştırmaların sınıf düzeylerine göre dağılımı Grafik 7'de verilmiştir.

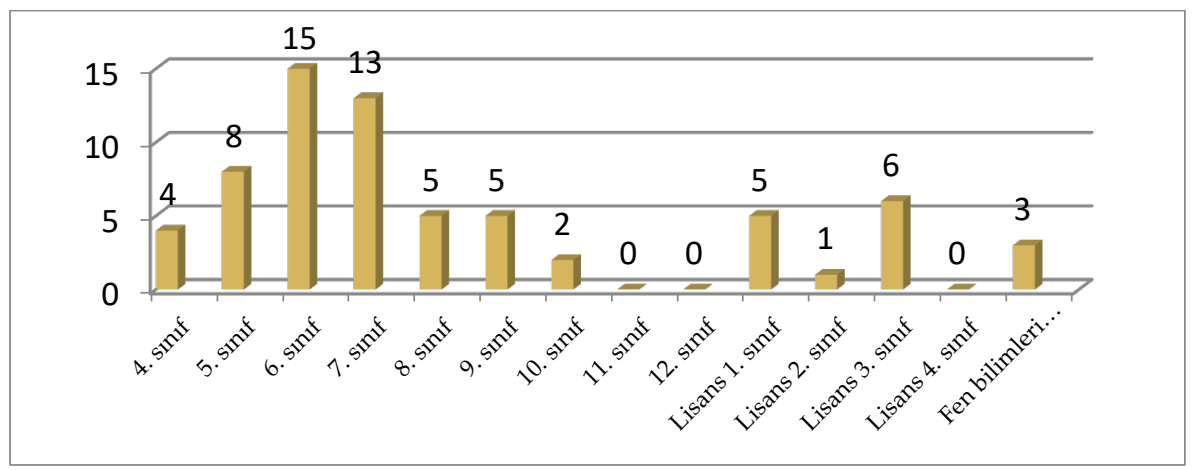

Grafik 7. Araştırmaların Sınıf Düzeylerine Göre Dă̆ılımı

Çalışmalar incelendiğinde; 65 çalışmanın düzeyi belli olan bir sınıfta yürütüldüğü fakat 2 çalışmada nitel araştırma yöntemlerinden doküman incelemesi kullanıldığından (A5 ve A12) herhangi bir sınıf düzeyi üzerine durulmadığı görülmüştür. Ayrıca iki araştırmada ise (A10 ve A30) farklı sınıflar birlikte kullanılmış ve çalışma kapsamında toplam 67 sınıf düzeyi incelenmiştir.

Çalışmada incelenen araştırmaların 4'ü ilkokul, 42'si ortaokul, 7'si lise ve 12 'si üniversite düzeyinde gerçekleştirilmiştir. Karma olan grupta en 
az iki farklı sınıf düzeyinden öğrenci grubu yer almaktadır. İlkokul öğrencileriyle yürütülen çalışmalarda öğrenci seviyesi olarak sadece 4 . sınıf kullanılmıştır. Bu durumun nedeni, psikomotor ve yazma becerilerinin 4. sınıf öğrencilerinde ilkokulun diğer sınıflarına devam eden öğrencilere nazaran daha fazla gelişmiş olması olabilir.

Ortaokul kademesinde gerçekleştirilen çalışmaların 8'i 5. sınıflarla, 15'i 6. sinıflarla, 13'ü 7. sinıflarla ve 5'i 8 . sinıflarla yürütülmüştür. Lise kademesinde, 11 ve 12. sinıflarda herhangi bir araştırma yapılmamışken 9. sinıflarda 5, 10. sinıflarda ise 2 araştırma yapılmıştır. Lisans öğrencileriyle yapılan araştırmaların 5'inin 1. sınıflarla, 1'inin 2. sinıflarla ve 6'sının 3. sinıflarla gerçekleştirilmesine karşın 4 . sinıflarla yürütülen herhangi bir çalışmaya rastlanmamıştır. Ayrıca ortaokul kademesinde başta öğretmen görüşlerini belirlemek, ölçme aracı geliştirmek ve yazma etkinliklerinin sinıfta uygulanma düzeylerini saptamak amaciyla 3 araştırma (A6, A47, A59) fen bilimleri öğretmenleriyle gerçekleştirilmiştir.

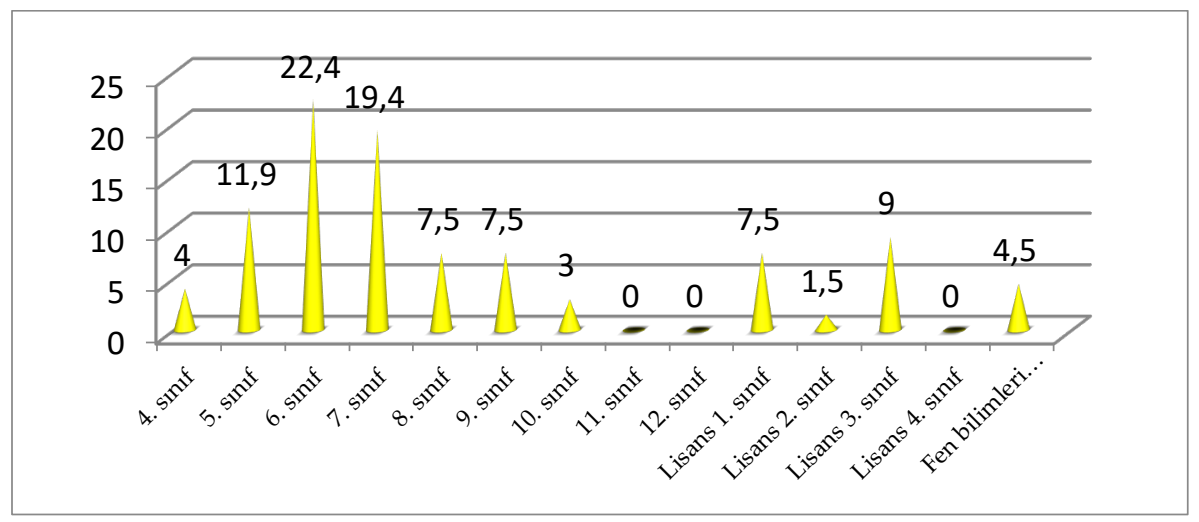

Grafik 8. Araştırmaların Sinıf Düzeylerine Göre Yüzdeleri

Çalışmaya dâhil edilen araştırmaların; yüzde 22,4'ü 6. sınıflarla, yüzde $19,4^{\prime}$ ü 7 . sinıflarla ve yüzde 11,9'u 5. sınıflarla yapılmıştır. 8. sınıf, 9. sınıf ve lisans 1. sınıfta yapılan araştırmaların her birinde, tüm yayınlar içerisinde yüzde 7,5'lik bir oran saptanmıştır. Lisans 3. sınıfta yüzde 9'luk, 4. sinıfta yüzde $6^{\prime}$ lık bir oran göze çarpmaktadır. 
Araştırmaların; yüzde 4,5'i ortaokul fen bilimleri öğretmenleriyle, yüzde $3^{\prime}$ ü 10 . sinıflarla ve yüzde $1,5^{\prime}$ i ise lisans 2 . sinıflarla gerçekleştirilmiştir.

\section{Öğrenme Amaçlı Yazma Araştırmalarının Örneklem Büyüklüğüne Göre Dağılımı}

Çalışmada incelenen tez ve makalelerin örneklem büyüklükleri dikkate alındığında 26-50 arası örneklem sayısının kullanıldığı araştırmaların diğer aralıklara göre daha fazla sayıda olduğu görülmektedir. Araştırmaların örneklem büyüklüklerine göre dağılımı Grafik 9'da verilmiştir.

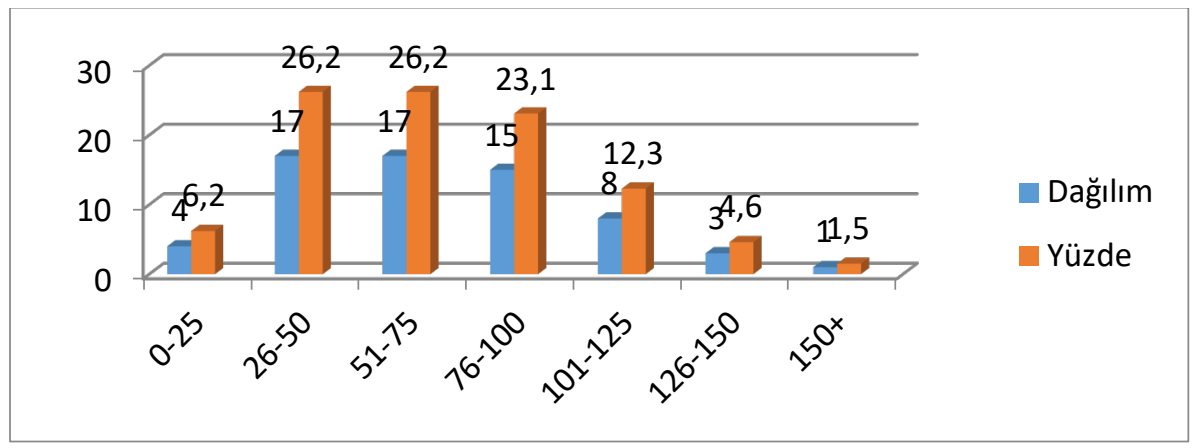

Grafik 9. Araştırmalarda Kullanılan Örneklem Büyüklüklerinin Dağıllım ve Yüzdeleri

Örneklem büyüklükleri; 0-25 kişi, 26-50 kişi, 51-75 kişi, 76-100 kişi, 101-125 kişi, 126-150 kişi ve 150'den fazla kişi olarak belirlenmiştir. Veriler incelendiğinde; 26-50 ve 51-75 aralığında seçilen örneklemin kullanıldığı araştırma sayısının diğer aralıklara nazaran daha fazla olduğu görülmektedir. Araştırmalarda belirlenen örneklem sayısında en çok kullanılan üçüncü aralık ise 76-100 olarak tespit edilmiştir. Sadece bir araştırmada örneklem sayısı 515 kişi (A43) olarak grafikte yer almaktadır.

Yüzdelik dilimler incelendiğinde $26-50$ ve 51-75 aralığında örneklemin kullanıldığı araştırma sayısı yüzde 26,2, 76-100 aralığında örneklemin kullanıldığı araştırma sayısı yüzde 23,1 olarak saptanmıştır. 
En düşük oran ise, yüzde 1,5 ile 150'den fazla örneklemin kullanıldığ 1 araştırmalara aittir.

\section{Öğrenme Amaçlı Yazma Araştırmalarının Kullanılan Veri Toplama Araçlarına Göre Dağılımı}

Çalışmada incelenen tez ve makalelerde kullanılan veri toplama araçları dikkate alındığında testlerin, ölçeklerin ve anketlerin diğer veri toplama araçlarına göre daha fazla oldukları ifade edilebilir. Araştırmalarda kullanılan veri toplama araçlarının dağılımı Grafik 10 ' da sunulmaktadır.

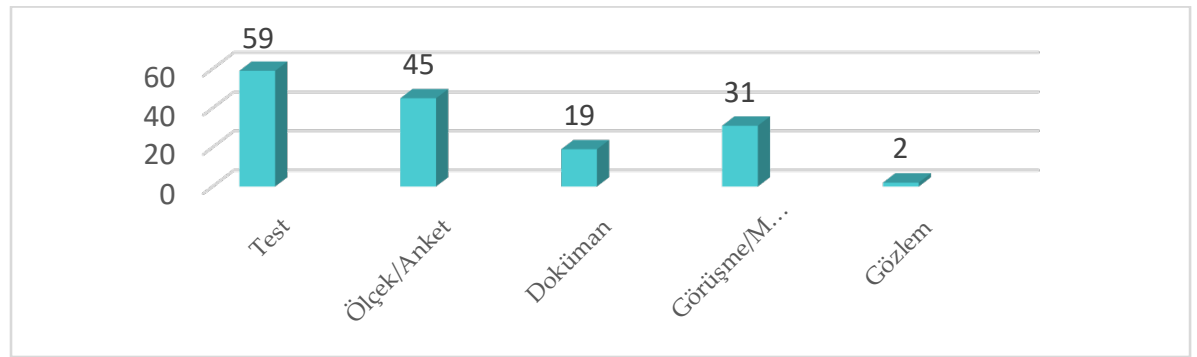

\section{Grafik 10. Araştırmalarda Kullanılan Veri Toplama Araçlarının Dağılımı}

Grafik 10'da görüldüğü üzere çalışma kapsamında incelenen 45 tez ve 22 makale olmak üzere toplam 67 yayının 59'unda veri toplama aracı olarak testler kullanılmıştır. Test başlı̆̆ı altında; akademik başarı testi $(n=47)$, kavram testi $(n=6)$ gibi bir konunun öğrenilme derecesini ölçmeye yönelik veri toplama araçlarının yanı sıra bilimsel süreç becerileri testi $(n=6)$ gibi veri toplama araçları yer almaktadır. İncelemeye alınan 67 araştırmanın 45'inde veri toplama aracı olarak ölçek ve anketler kullanılmıştır. Bu başlık altında; tutum ölçeği $(n=24)$, anket $(n=5)$, öz yeterlik ölçeği $(n=3)$, biliş üstü ölçeği $(n=3)$, eleştirel düşünme ölçeği $(n=2)$, güdülenme ölçeği $(n=1)$, öğretim stratejileri ölçeği $(n=1)$, pedagojik alan bilgisi ölçeği ( $n=1)$, konu alan bilgisi ölçeği $(n=1)$, kaygı ölçeği $(n=1)$, motivasyon ölçeği $(n=1)$ ve farkındalık ölçeği $(n=1)$ gibi veri toplama araçları bulunmaktadır. Görüşme, araştırmaların 31'inde veri toplama aracı olarak kullanılmıştır. Bu araçlar daha çok yarı yapılandırılmış görüşme tekniği ve görüş formundan oluşmaktadır. Genellikle 
destekleyici ikincil veri toplama aracı olarak nitelendirilen dokümanlar; araştırmaların 19'unda kullanılmıştır. Ayrıca araştırmaların sadece 2 'sinde araştırmacı ve öğretmen gözlemlerinin veri toplama aracı olarak kullanıldığı görülmüştür.

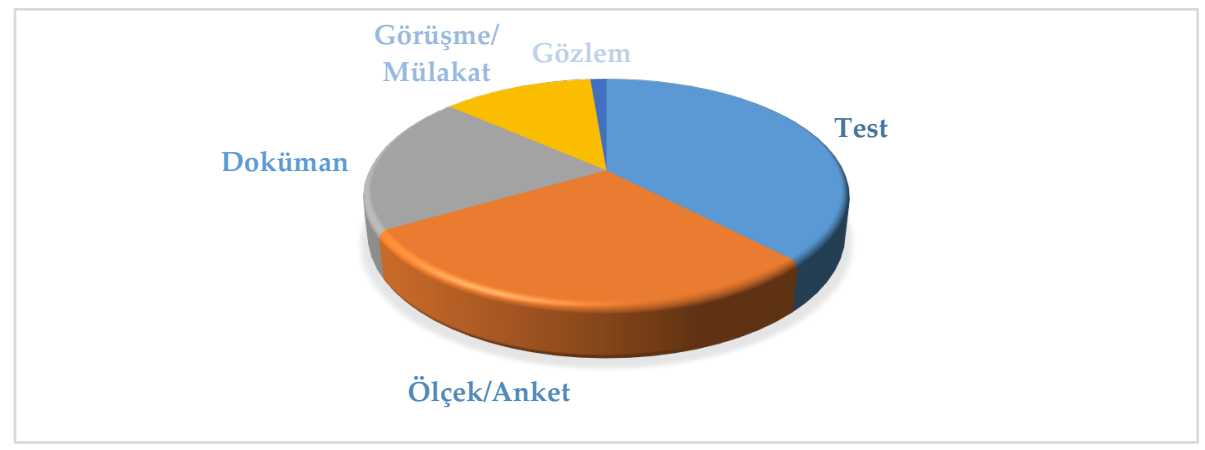

Grafik 11. Araştırmalarda Kullanılan Veri Toplama Araçlarının Yüzdeleri

Veri toplama aracı olarak araştırmaların; yüzde 37,8 'inde testler, yüzde 28,8'inde ölçek ve anketler, yüzde 19,9'unda görüşme ve mülakatlar kullanılmıştır. Ayrıca dokümanlar, incelenen araştırmaların yüzde 12,2'sini oluştururken gözlemler yüzde 1,3'ünü oluşturmaktadır. Grafikte incelenen sonuçlara göre, araştırmalarda veri toplama aracı olarak en fazla testlerin en az ise gözlemin kullanıldığı söylenebilir.

\section{Öğrenme Amaçlı Yazma Araştırmalarının Gerçekleştirildiği Uygulama Sürelerine Göre Dağılımı}

Çalışmada incelenen tez ve makalelerin gerçekleştirildiği uygulama süreleri dikkate alındığında 5-7 hafta arasında tamamlanan araştırmaların diğer hafta aralıklarıyla sınırlı olan çalışmalara göre daha fazla olduğu söylenebilir. Araştırmaların gerçekleştirildiği uygulama sürelerinin dağılımı Grafik 12'de sunulmuştur.

Çalışmaya dâhil edilen 67 araştırmanın 2'sinde nitel araştırma yöntemlerinden doküman incelemesi kullanılmasından (A5 ve A12) ve 13'ünde bir uygulama süresi olmasına karşın bu sürenin belirtilmemesinden dolay1 (A6, A30, A34, A35, A41, A45, A46, A47, A49, A53, A59, A61 ve A67) 52 yayın uygulama süresi açısından incelenmiştir. 
Grafik 12' de araştırmaların uygulama süreleri incelendiğinde, 52 yayının en fazla 5-7 hafta arasında tamamlandığ $1(n=23)$ ifade edilebilir. Araştırmaların 15'inde 8-10 hafta arası uygulama yapılmışken 8'inde 2-4 hafta arası uygulama yapılmıştır. Ayrıca araştırmaların 5'i 11-13 hafta arasında, 1'i ise (A66) 14-16 hafta arasında gerçekleştirilmiştir.

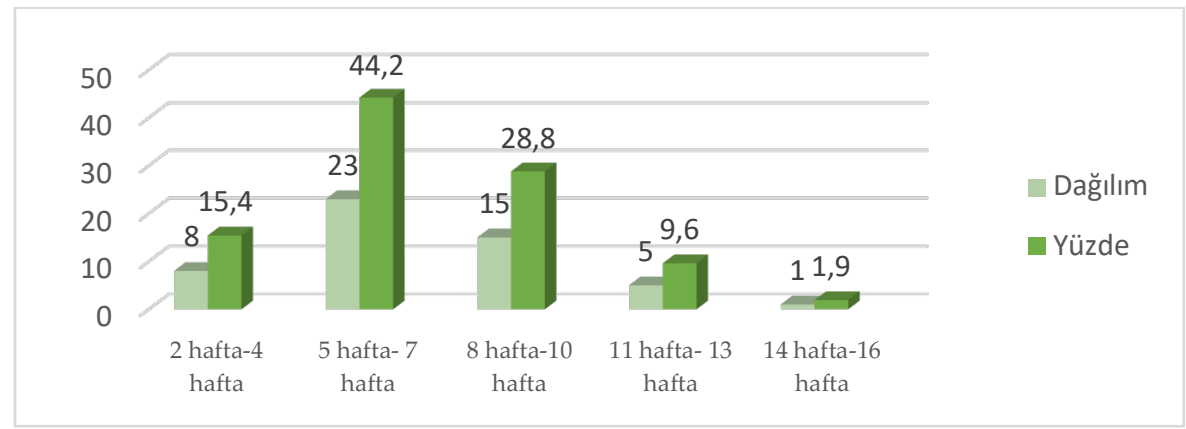

Grafik 12. Araştırmaların Gerçekleştirildiği Uygulama Sürelerinin Dağılım ve Yüzdeleri

Uygulama süresi olarak araştırmaların; yüzde 44,2'sinde 5-7 hafta arası, yüzde 28,8'inde 8-10 hafta arası, yüzde 15,4'ünde 2-4 hafta arası uygulamalar gerçekleştirilmiştir. Ayrıca 11-13 hafta arası gerçekleştirilen uygulamalar, incelenen araştırmaların yüzde 15,4'ünü oluştururken 1416 hafta arası gerçekleştirilen uygulamalar yüzde 9'unu oluşturmaktadır. Grafikte incelenen sonuçlara göre, araştırmalarda uygulama süresi olarak en fazla 5-7 hafta arası en az ise 14-16 hafta arası uygulama gerçekleştirildiği görülmüştür.

\section{Öğrenme Amaçlı Yazma Araştırmalarının Kullanılan Istatistiksel Analizlere Göre Dağılımı}

Çalışmada incelenen tez ve makalelerin değerlendirilmesinde kullanılan veri analiz yöntemleri dikkate alındığında parametrik testlerin nonparametrik testlere göre daha fazla kullanıldıkları göze çarpmaktadır. Araştırmaların değerlendirilmesinde kullanılan istatistiksek analizlerin dağılımı Tablo 4 'te sunulmuştur. 
Tablo 4. İncelenen araştırmaların değerlendirilmesinde kullanılan istatistiksel analiz yöntemleri

\begin{tabular}{llll}
\hline Yöntem & İstatistiksel Analiz & $f$ & $\mathbf{\%}$ \\
\hline \multirow{6}{*}{ Nicel } & Bağımlı Örneklemler T Testi & 24 & 15,9 \\
& Bağımsız Örneklemler T Testi & 30 & 19,9 \\
& Tek Yönlü Varyans Analizi (ANOVA) & 19 & 12,6 \\
& Tek Yönlü Kovaryans Analizi (ANCOVA) & 11 & 7,3 \\
& Kruskal Wallis Testi & 5 & 3,3 \\
& Mann Whitney U Testi & 14 & 9,3 \\
& Wilcoxon İşaretli Sıralar Testi & 9 & 6,0 \\
& Pearson Korelasyon Testi & 1 & 0,7 \\
& Betimsel İstatistik & 2 & 1,3 \\
\hline \multirow{3}{*}{ Nitel } & İcrik Analizi & 20 & 13,2 \\
& Betimsel Analiz & 14 & 9,3 \\
& Puanlama Anahtarl/Rubrik & 2 & 1,3 \\
\hline Toplam & - & 151 & 100 \\
\hline
\end{tabular}

İncelenen araştırmalarda kullanılan istatistiksel analizler, yazarların araştırmalarda belirttikleri bilgilere dayanılarak değerlendirilmiştir. Çalışma kapsamına, dağılımın normalliğini tespit etmek için kullanılan shapiro-wilk ve kolmogorov-smirnov analizleri dâhil edilmemiştir. Tablo 4'e göre incelenen araştırmalarda nicel veri analizlerinin $(n=115)$ ağırlıklı olarak kullanıldığı görülmektedir. Ayrıca nicel veri analiz yöntemlerinden en çok bağımsız örneklemler $t$ testinin $(n=30, \% 19,9)$, nitel veri analiz yöntemlerinden ise en çok içerik analizinin $(n=20, \% 13,2)$ kullanıldığı saptanmıştır. Veri toplama aracı olarak kullanılan görüşmelerin $(n=31)$ çoğunun nasıl değerlendirildiği konusunda doğrudan bilgiye yer verilmemiştir. Bu gerçekten yola çıkılarak ele alınan tez ve makaleler dikkatli bir şekilde incelenmiş ve yazılı açıklamalara göre bir analiz yöntemi belirlenmeye çalışılmıştır.

\section{Öğrenme Amaçlı Yazma Araştırmalarının İncelenen Dokümanlara Göre Dağılımı}

Çalışmada incelenen tez ve makalelerin dağılımı dikkate alındığında lisansüstü tezlerin makalelere göre daha fazla sayıda olduğu ifade edilebilir. Araştırmaların doküman türlerine göre dağılımı Grafik 13'te sunulmaktadır. 


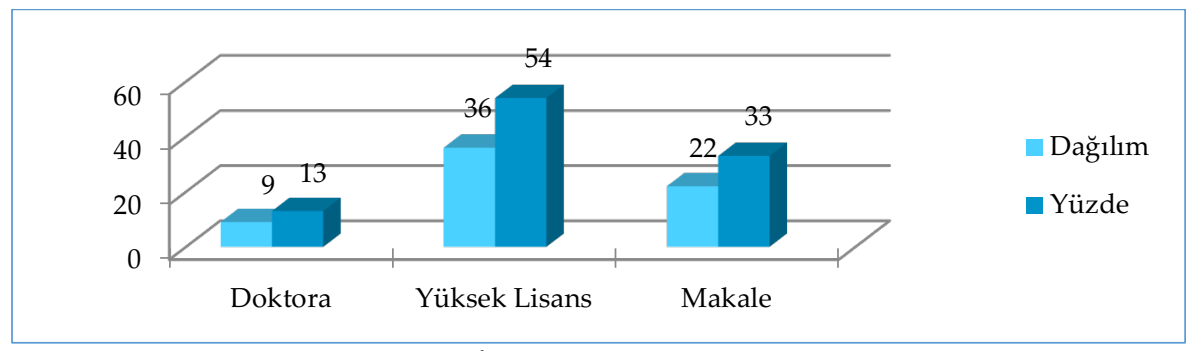

Grafik 13. Araştırmada İncelenen Dokümanların Dağılım ve Yüzdeleri

Çalışma kapsamına alınan araştırmaların doküman türleri incelendiğinde $45^{\prime}$ inin tez, 22 'sinin ise makale olduğu görülmektedir. Bu tezlerin 9'u doktora, 36'sı ise yüksek lisans tezi olarak belirlenmiştir. İncelenen araştırmaların doküman türleri içerisindeki yüzdelik dilimleri göz önüne alındığında yüzde 13'ü doktora tezi, yüzde 33'ü makale, yüzde 54'ü ise yüksek lisans tezi olarak saptanmıştır. 2016-2020 yılları arasında tamamlanan öğrenme amaçlı yazma tezlerinin sayı ve oranlarını ortaya koyan İncirci (2020), bu yıllar arasında tamamlanan doktora tezinin bir tane olduğunu ve tezlerin yüzde 11'ine denk geldiğini belirlemiştir. Ayrıca araştırmacı, tamamlanan yüksek lisans tezlerinin ise sekiz tane olduğunu ve tezlerin yüzde $89^{\prime}$ luk bir dilimini kapsadığını ifade etmiştir. Bu çalışmada ulaşılan sonuçlar İncirci (2020) tarafından gerçekleştirilen araştırmayla benzerlik göstermektedir.

\section{Öğrenme Amaçlı Yazma Araştırmalarının Çalışma Yerlerine Göre Dağılımı}

Çalışmada incelenen tez ve makalelerin çalışma yerleri dikkate alındığında, uygulamaların en çok illerde yapıldığ Araştırmaların çalışma yerlerine göre dağılım ve yüzdeleri Grafik 14'te verilmiştir.

Çalışma kapsamında incelenen araştırmaların 65'inde çalışma yerine ulaşılmış fakat 2 araştırmada (A5 ve A12) doküman incelemesi kullanıldığından herhangi bir çalışma yeri bulunamamıştır. İncelenen araştırmaların 


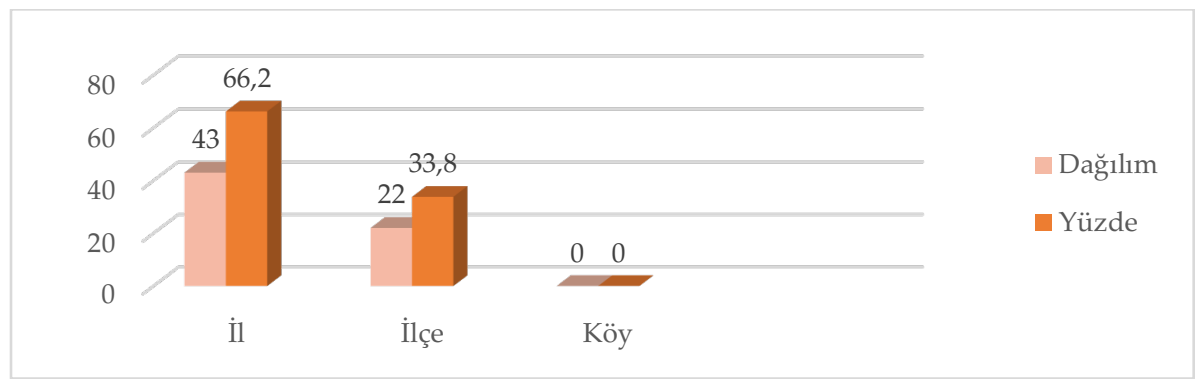

Grafik 14. Araştırmaların Yapıldı̆̆ı Yerlere Göre Dağılım ve Yüzdeleri

43'ü il merkezlerinde 22'si ise ilçe merkezlerinde yürütülmüştür. Araştırmalardaki çalışma yerlerinin tüm yayınlar içerisindeki yüzdelerine bakıldığında il merkezlerinde yürütülen araştırmaların yüzde 66,2; ilçe merkezlerinde yürütülen araştırmaların ise yüzde 33,8 olduğu görülmüştür. Ayrıca köy okullarında gerçekleştirilen hiçbir uygulamaya rastlanmaması dikkat çekicidir.

\section{Öğrenme Amaçlı Yazma Araştırmalarının Çalışma Bölgelerine Göre Dağılımı}

Çalışmada incelenen tez ve makalelerin çalışma bölgeleri dikkate alındığında araştırmaların en çok Doğu Anadolu Bölgesi'nde gerçekleştirildiği ifade edilebilir. Araştırmaların çalışma bölgelerine göre dağılım ve yüzdeleri Grafik 15 'te sunulmuştur.

Çalışma kapsamında incelenen araştırmaların 64'ünde çalışma bölgesi tespit edilmiştir. İki araştırmada (A5 ve A12) doküman incelemesi kullanıldığından ve 1 araştırmada çalışma bölgesi belirtilmediğinden dolayı (A64) bu çalışmalar grafiğe yansıtılmamıştır. İncelenen araştırmaların 25'i Doğu Anadolu Bölgesi'nde; 11'i Karadeniz Bölgesi'nde ve 10'u Marmara Bölgesi'nde yürütülmüştür. Ayrıca araştırmaların en az uygulandığı bölge, Güneydoğu Anadolu Bölgesi olarak saptanmıştır. Araştırmalardaki çalışma bölgelerinin tüm yayınlar içerisindeki yüzdelerine bakıldığında Doğu Anadolu Bölgesi'nde yürütülen araştırmaların yüzde 39; Karadeniz Bölgesi'nde yürütülen araştırmaların yüzde 17,2; Marmara Bölgesi'nde yürütülen araştırmaların ise yüzde 15,6 olduğu göze çarpmaktadır. Ayrıca 
araştırmalar içerisinde en düşük oran yüzde 1.6 ile Güneydoğu Anadolu Bölgesi'nde saptanmıştır.

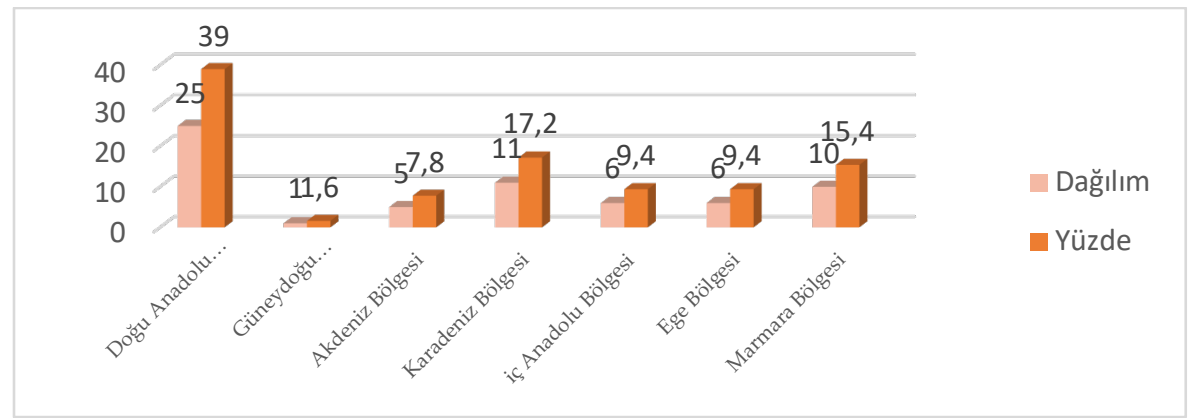

Grafik 15. Araştırmaların Yapıldı̆̆ı Bölgelere Göre Dă̆ılım ve Yüzdeleri

\section{Öğrenme Amaçlı Yazma Araştırmalarının Sonuçlarına Göre Dağılımı}

Çalışmada incelenen tez ve makalelerin sonuçları dikkate alındığında en çok akademik başarıyı olumlu yönde etkileyen araştırmalara rastlanmıştır. Araştırmaların sonuçlarına göre dağılım ve yüzdeleri Tablo 5 'te verilmiştir.

Öğrencilerin bilişsel ve duyuşsal becerilerinin ölçülmeye çalışıldığ araştırmalardan elde edilen sonuçlar dikkate alındığında, yüzde 31,5 ile akademik başarıya etkinin pozitif yönde olduğu belirlenmiştir. Diğer taraftan yüzde 9,7 ile tutumda anlamlı farkın deney grubu lehine çıktığ 1 araştırmalar ikinci sırada yer almaktadır. Tutumda herhangi bir anlamlı farkın tespit edilemediği araştırmaların oranı, tüm yayınlar içerisinde yüzde 8,9 olarak bulunmuştur. Ayrıca pozitif etkiye sahip olan ve yüzde 7,3 ile öğrenme, yüzde 6,5 ile kalıcılık ve yüzde 5,6 ile kavramsal anlama en fazla ulaşılan sonuçlar arasında yer almaktadır. Düşük etki sonucuna ulaşıldığı ve olumsuz etki başlığı altında değerlendirilen 3 araştırma ise incelenen yayınların yüzde 2,4'ünü kapsamaktadır.

Çalışma kapsamında incelenen yayınlardan A12 kodlu araştırma, öğrenme amaçlı yazmanın etkili kullanımı için gerekli koşulları belirlemeye çalıştı̆̆ından; A47 kodlu araştırma, sadece öğrenme amaçlı yazma üzerine öğretmen görüşlerini aldığından ve A55 kodlu araştırma, deney ve kontrol gruplarının öğrenme amaçlı yazma uygulamalarını 
kullanarak birbirleriyle olan farklılıkları saptamaya çalıştığından dolayı dikkate alınmamıştır. Böylece 64 araştırma, sonuçlarına göre değerlendirilmeye alınmıştır.

Tablo 5. Araştırmaların sonuçlarına göre dağılım ve yüzdeleri

\begin{tabular}{|c|c|c|c|}
\hline Sonuçlar & & $f$ & $\%$ \\
\hline \multirow{17}{*}{ Olumlu Etki } & Akademik başarı & 39 & 31,5 \\
\hline & Tutum & 12 & 9,7 \\
\hline & Öğrenme & 9 & 7,3 \\
\hline & Kalıcilık & 8 & 6,5 \\
\hline & Kavramsal anlama & 7 & 5,6 \\
\hline & Bilimsel süreç becerileri & 3 & 2,4 \\
\hline & Biliş üstü beceri & 2 & 1,6 \\
\hline & Kavram yanılgıları & 2 & 1,6 \\
\hline & Güdülenme & 2 & 1,6 \\
\hline & Motivasyon & 2 & 1,6 \\
\hline & Kaygi & 2 & 1,6 \\
\hline & Öz yeterlik inancı & 2 & 1,6 \\
\hline & Epistemolojik inanç & 1 & 0,8 \\
\hline & Problem çözme becerisi & 1 & 0,8 \\
\hline & Öğrenme stratejileri & 1 & 0,8 \\
\hline & Kavrama & 1 & 0,8 \\
\hline & Eleştirel düşünme becerisi & 1 & 0,8 \\
\hline \multirow{10}{*}{ Etkisiz } & Tutum & 11 & 8,9 \\
\hline & Akademik başarı & 3 & 2,4 \\
\hline & Öğrenme & 3 & 2,4 \\
\hline & Bilimsel süreç becerileri & 3 & 2,4 \\
\hline & Öz yeterlik inancı & 1 & 0,8 \\
\hline & Eleştirel düşünme becerisi & 1 & 0,8 \\
\hline & Alan öğretimi bilgi ve beceri düzeyi & 1 & 0,8 \\
\hline & Biliş üstü beceri & 1 & 0,8 \\
\hline & Bilişsel yapı & 1 & 0,8 \\
\hline & Farkındalık & 1 & 0,8 \\
\hline Olumsuz Etki & Anlama düzeyi & 3 & 2,4 \\
\hline Toplam & & 124 & 100 \\
\hline
\end{tabular}

Tablo 5 incelendiğinde; araştırmalarda öğrenciler üzerinde olumlu etkilerin olduğu, herhangi bir etkinin olmadığı ve düşük etkinin olduğu şeklinde gruplandırılan bulgulara ulaşılmıştır. Bulgular göz önünde bulundurulduğunda; incelenen araştırmalar arasında öğrenme amaçlı yazmanın en çok öğrencilerin akademik başarılarına katkı sağladığ görülmüştür (n=39). Öğrenme amaçlı yazmanın; öğrencilerin derse veya sürece yönelik tutum ve öğrenmelerine etkisi incelenmiş ve bu araştırmaların 12'sinde tutum ve 9'unda öğrenme üzerine pozitif bir etki olduğu saptanmıştır. On bir araştırmada tutum ve 3 araştırmada ise 
öğrenme üzerine herhangi bir etki olmadığı belirlenmiştir. Benzer bir durum akademik başarı, bilimsel süreç becerileri, öz yeterlik inancı, biliş üstü beceri ve eleştirel düşünme becerisinde görülmüştür. Öğrenme amaçlı yazma uygulamalarının 39 araştırmada akademik başarıyı, 3 araştırmada bilimsel süreç becerilerini, 2 araştırmada öz yeterlik inancını, 2 araştırmada biliş üstü becerilerini ve 1 araştırmada eleştirel düşünme becerilerini artırdığ 1 tespit edilmiştir. Aksine 3 araştırmada akademik başarı, 3 araştırmada bilimsel süreç becerileri, 1 araştırmada öz yeterlik inancı, 1 araştırmada biliş üstü beceri ve 1 araştırmada eleştirel düşünme becerisi üzerine bir etki görülmediği saptanmıştır. Ayrıca 3 araştırmada öğrencilerin anlama düzeylerinin düşük seviyede kalması, dikkat çeken diğer bir sonuçtur.

\section{Öğrenme Amaçlı Yazma Araştırmalarının Yararlanılan Kaynak Sayılarına Göre Dağılımı}

Çalışmada incelenen tez ve makalelerin kaynak sayıları dikkate alındığında araştırmalarda en çok 51-100 arasında kaynak kullanıldığ 1 ifade edilebilir. Araştırmaların kaynak sayılarına göre dağılım ve yüzdeleri Grafik 16'da sunulmaktadır.

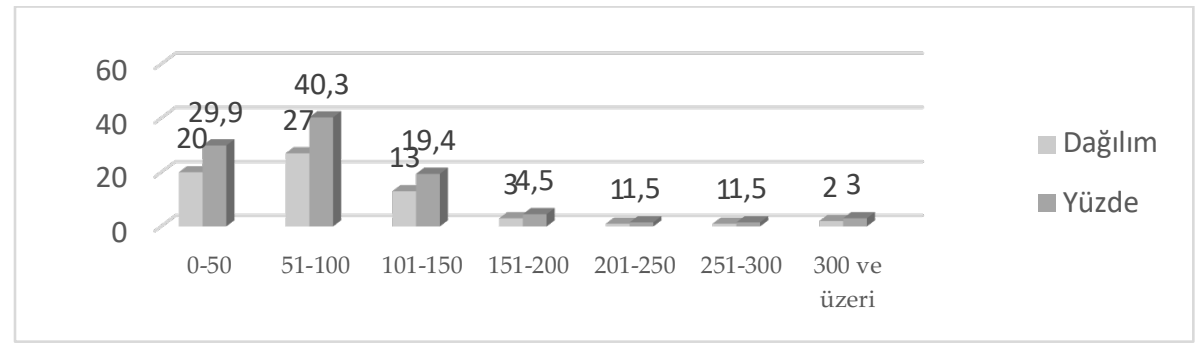

Grafik 16. Araştırmalarda Kullanılan Kaynak Sayılarının Dağılım ve Yüzdeleri

Kaynak sayılar1; 0-50, 51-100, 101-150, 151-200, 201-250, 251-300 ve 300 üzeri şeklinde belirtilmiştir. Veriler incelendiğinde; $0-50$ ve 51-100 aralığında kullanılan kaynak sayısının diğer aralıklara nazaran daha fazla olduğu görülmektedir. Araştırmalarda belirlenen kaynak sayısında en çok kullanılan üçüncü aralık ise 101-150 olarak belirlenmiştir. Sadece iki araştırmada (A50 ve A66) kaynak sayısı 300 üzerindedir. Yüzdelik 
dilimler incelendiğinde 51-100 aralığında kullanılan kaynak sayısı yüzde 40,3 olarak saptanmışken 0-50 aralığında kullanılan kaynak sayısı yüzde 29,9 olarak saptanmıştır. En düşük oran ise, yüzde 1,5 ile 201-250 ve 251300 kaynak sayısının kullanıldığı araştırmalara aittir.

\section{Sonuç ve Öneriler}

İncelemeler doğrultusunda araştırmaların son yıllara doğru daha çok yapıldığ 1 ve yayınların en fazla 2019 yilında en az ise 2008 yılında tamamlandığı görülmüştür. Değerlendirilen yayınların en çok Atatürk Üniversitesi'nde olmak üzere 19 farklı üniversitede ve üniversitelerin eğitim bilimleri enstitülerinde hazırlandıkları ifade edilebilir. Araştırmalar dikkatli bir şekilde analiz edildiğinde; amaçların daha çok konuya ve derse yönelik olduğu ve sonrasında ise beceriye yönelik gerçekleştirildiği iddia edilebilir. Konuya veya derse yönelik olarak gerçekleştirilen amaçların, özellikle akademik başarı $(n=42)$, tutum $(n=24)$ ve öğrenme düzeyinin ( $n=17)$ belirlenmesi üzerine yapıldı̆̆ 1 söylenebilir.

Öğrenme amaçlı yazmanın etkisinin belirlenmeye çalışıldığ araştırmaların genellikle deneysel olmasına karşın bu araştırmaların 28'i nitel verilerle desteklenmiş çoklu yöntem araştırmalarıdır. Bu sonuç, öğrenme amaçlı yazma üzerine yapılan Türkçe araştırmaların yarısına yakınının nicel ve çoklu yöntemler doğrultusunda yürütüldüğünü göstermektedir. Öğrenme amaçlı yazmanın çalışıldığ 1 konuların çoğunlukla fen bilimleri ve matematik alanlarından seçildiği, sosyal bilimler alanında ise ilk çalışmanın 2010 yılında eğitim psikolojisi dersinde gerçekleştirildiği görülmüştür. Araştırmalarda Türkçe, Biyoloji, Eğitim Psikolojisi ve Matematik Öğretimi en az kullanılan konu alanları olarak göze çarpmaktadır. Çalışma kapsamında incelenen araştırmalarda en fazla uygulama yapılan örneklem kademesi ortaokul olarak belirlenmiştir. Ayrıca en az uygulamanın ilkokul öğrencileriyle gerçekleştirildiği ve öğretmenlerle yapılan araştırmaların (A6, A47 ve A59) ortaokulda yapıldığı dikkat çeken bir diğer husustur.

Çalışma kapsamında ele alınan araştırmaların uygulamaları ilkokul seviyesi olarak sadece 4. sinıflarda $(n=4)$ yapılmıştır. Ortaokul öğrencileriyle gerçekleştirilen araştırmalar, en fazla 6. sinıflarla $(n=15)$ en az 8. sinıflarla $(n=5)$ yürütülmüştür. Lise kademesinde, 11 ve 12. 
sınıflarla; lisans kademesinde, 4. sınıflarla yürütülen bir çalışmaya rastlanmamıştır. Araştırmacıların sınavlara hazırlanan son sınıf öğrencilerini daha zor motive edebileceklerini düşünmesi, bu durumun gerekçesi olabilir. Araştırmalarda daha çok 26-50 ve 51-75 arası örneklem büyüklüğü kullanılırken 150'den fazla örneklemin kullanıldığ sadece bir araştırmaya (A43) rastlanmıştır. 45 tez ve 22 makale olmak üzere toplam 67 yayının 59'unda veri toplama aracı olarak testler (başarı testi, kavram testi, bilimsel süreç becerileri testi) kullanılmıştır. İkinci en çok kullanılan veri toplama aracı ölçek ve anket (tutum ölçeği, öz yeterlik ölçeği, biliş üstü ölçeği, eleştirel düşünme ölçeği, güdülenme ölçeği, öğretim stratejileri ölçeği, pedagojik alan bilgisi ölçeği, konu alan bilgisi ölçeği, kaygı ölçeği, motivasyon ölçeği, farkındalık ölçeği, anket), en az kullanılan veri toplama aracı ise gözlem olarak belirlenmiştir. Görüşme, yayınların 31'inde veri toplama aracı olarak kullanılmıştır. Bu yayınlarda daha çok yarı yapılandırılmış görüşmelerin öne çıktığı söylenebilir.

Araştırmalar dikkatli bir şekilde analiz edildiğinde; genelde 5-7 hafta arasında gerçekleştirildiği söylenebilir. Daha sonra en fazla uygulama yapılan süre 8-10 hafta arası olarak göze çarpmaktadır. En az kullanılan zaman aralığı ise 1 araştırma için (A66) 14-16 hafta arasıdır. Analiz yöntemleri dikkate alındığında parametrik testlerin nonparametrik testlere oranla daha fazla kullanıldıkları ifade edilebilir. Ayrıca araştırmalarda daha çok nicel veri analiz yöntemlerinin $(n=115)$ kullanıldığını söylemek mümkündür. Bununla birlikte nicel veri analiz yöntemlerinden en fazla bağımsız örneklemler $t$ testinin $(n=30)$ nitel veri analiz yöntemlerinde ise en fazla içerik analizinin $(n=20)$ kullanıldığ 1 görülmektedir. Genelde görüşmelerin $(n=31)$ nasıl değerlendirildiği hakkında herhangi bir bilginin verilmemesi dikkat çeken bir diğer husustur. Çalışmada incelenen doküman türleri dikkate alındığında tezlerin makalelere göre daha fazla olduğu görülmektedir. Tezlerin 9'u doktora, 36'sı yüksek lisans tezi olarak saptanmıştır. Araştırmalarda kullanılan doküman türlerinden makale ise yayınların sadece 22'sini kapsamaktadır.

Öğrenme amaçlı yazmayla ilgili köy okullarında yapılan herhangi bir araştırmaya rastlanmamıştır. İncelenen araştırmalarda öğrenme amaçlı yazma, en fazla il merkezlerinde bulunan okullarda gerçekleştirilmiştir. Bu uygulamalar daha çok Doğu Anadolu Bölgesi'nde $(n=25)$ en az ise 
Güneydoğu Anadolu Bölgesi'nde $(n=1)$ yapılmıştır. Araştırmaların sonuçları göz önünde bulundurulduğunda; öğrenme amaçlı yazmanın en çok öğrencilerin akademik başarılarına $(n=39)$, tutumlarına $(n=12)$, öğrenmelerine $(n=9)$, öğrenmelerin kalıcılığına $(n=8)$ ve kavramsal öğrenmelerine $(n=7)$ yardımcı olduğu belirlenmiştir. Öğrencilerin tutumlarına $(n=11)$, akademik başarılarına $(n=3)$, öğrenmelerine $(n=3)$ ve bilimsel süreç becerilerine $(n=3)$ yönelik herhangi bir etkinin saptanamadığı araştırmaların olması dikkat çekici bulunmuştur. Ayrıca dikkat çeken bir diğer husus ise 3 araştırmada öğrencilerin anlama düzeyleri bakımında düşük seviyede olduklarının belirlenmesidir. Diğer bir yandan araştırmalarda 0-50 ile 51-100 arasında kullanılan kaynak sayısının diğer aralıklara nazaran daha fazla olduğu gözlenmiştir. Sadece iki araştırmada (A50 ve A66) 300'den fazla kaynak kullanılmıştır.

Öğrenme amaçlı yazma üzerine yapılan meta-sentez araştırmalarının analiz kriterlerine anahtar kelimeler ve atıf sayıları dâhil edilerek yeni çalışmalar yapılabilir. Aynı dönemde yayınlanan çalışmaların atıf sayıları mukayese edilerek bir sonuca varılabilir. Çalışmaları gerçekleştiren araştırmacı veya araştırmacıların mensup oldukları anabilim dalları diğer bir analiz ölçütü olarak düşünülebilir. 


\title{
EXTENDED ABSTRACT
}

\section{An Analysis of the Researches on Writing to Learn in Turkey: A Meta-Synthesis Study}

\author{
Bünyamin İspir- Ali Yıldız \\ Atatürk University
}

The purpose of the study is to analyze the theses and articles made in Turkey on writing to learn through meta-synthesis method and determine how they are distributed according to set criteria. This research is a thematic content analysis, that is, a meta-synthesis study. Meta-synthesis studies are based on the qualitative findings of research conducted in a particular field; It is a method that aims to interpret, reveal similar and differences, evaluate and make new inferences (Polat and Ay, 2016). In addition, meta-synthesis studies include qualitative researches carried out in a specific field, and the qualitative understanding and the comparative presentation of similarities and differences (Çalık and Sözbilir, 2014). As quantitative or qualitative research methods are used throughout the investigated studies, it has been observed that the studies are suitable for meta-synthesis. In this study, the researchers analyzed 45 theses and 22 articles about writing to learn which were carried out in Turkey by the end of 2020 .

In line with the investigations, it was observed that the number of studies has increased in recent years and the most publications were completed in 2019 and the least was in 2008. It could be stated that the evaluated publications were prepared in 19 different universities, mostly in Atatürk University, and in educational sciences institutes of universities. When the researches were analyzed carefully, it could be argued that the purposes are oriented toward subject and lesson mostly, and then are skill. It can be said that the purposes achieved for the subject or the lesson are especially based on the determination of academic achievement $(n=42)$, attitude $(n=24)$ and learning level $(n=$ 17).

Although the studies in which the effect of writing for learning is tried to be determined are generally experimental, 28 of these studies 
were multi-method studies supported by qualitative data. This result showed that almost half of the Turkish studies on writing for learning purposes were conducted in the direction of quantitative and multiple methods. It was observed that the subjects in which writing for learning purposes were studied were mostly chosen from the fields of science and mathematics, and the first study in the field of social sciences was conducted in the educational psychology course in 2010. Turkish, Biology, Educational Psychology and Mathematics Teaching stand out as the least used subject areas in researches. In the studies examined within the scope of the study, the most applied sample level was determined as secondary school. In addition, it is another remarkable point that the least application was carried out with primary school students and that the studies conducted with teachers (A6, A47 and A59) were conducted in secondary school.

The implementation of the studies considered within the scope of the study were conducted only in 4th grades $(n=4)$ as primary school level. Studies with secondary school students were conducted with at most 6th graders $(n=15)$ and at least 8 th graders $(n=5)$. There is no study conducted with the 11th and 12th grades at the high school level and the 4th grades at the undergraduate level. Researchers' belief that they can hardly motivate senior students preparing for exams may be the reason for this situation. While the sample size between 26-50 and 51-75 is mostly used in the studies, only one study (A43) using more than 150 samples was determined. Tests (achievement test, concept test, scientific process skills test) were used as data collection tools in 59 of 67 publications, including 45 theses and 22 articles. The second most used data collection tool was scale and questionnaire (attitude scale, selfefficacy scale, metacognition scale, critical thinking scale, motivation scale, teaching strategies scale, pedagogical content knowledge scale, subject area knowledge scale, anxiety scale, motivation scale, awareness scale, questionnaire), and the least used data collection tool was determined as observation. While interviews were used as data collection tools in 31 of the publications, semi-structured interviews were mostly used in these publications.

When the studies are analyzed carefully, it can be said that they were generally carried out between 5-7 weeks. The second most used study 
period was between 8-10 weeks. The least used time frame for 1 study (A66) was between 14-16 weeks. Considering the analysis methods, it can be stated that parametric tests were used more than nonparametric tests. In addition, it is possible to say that quantitative data analysis methods $(n=115)$ were mostly used in studies. However, it is seen that among the quantitative data analysis methods, independent samples $t$ test $(n=30)$ was used the most, and content analysis $(n=20)$ was the most used in qualitative data analysis methods. Another remarkable point is that no information was given about how interviews and interviews $(n=31)$ would be evaluated in general. Considering the types of documents examined in the study, it is seen that theses were more than articles. While 9 of the theses were doctoral dissertations, 36 of them were determined as master theses. The article among the document types used in research covered only 22 of the publications.

No research on writing for learning purposes was found in village schools. In the researches examined, writing for learning purposes was mostly carried out in provincial schools. These applications were mostly carried out in the Eastern Anatolia Region $(\mathrm{n}=25)$ and at least in the Southeastern Anatolia Region $(n=1)$. Considering the results of the studies, it was determined that writing for learning purposes mostly helped student academic achievement $(n=39)$, attitudes $(n=12)$, learning $(n=9)$, permanence of learning $(n=8)$ and conceptual learning $(\mathrm{n}=7)$. It was found remarkable that there were studies in which no effect was detected on students' attitudes $(n=11)$, academic achievement $(n=3)$, learning $(n=3)$ and scientific process skills $(n=3)$.

New studies can be made by including keywords and citation numbers in the analysis criteria of meta-synthesis researches on writing for learning purposes. A conclusion can be reached by comparing the number of citations of the studies published in the same period. The departments of the researcher or researchers who carried out the studies can be considered as another analysis criterion. 


\section{Kaynakça / References}

Akar, M. S. (2007). Laboratuvar dersinde yazma metinleri oluşturmanın ve ana kullanımının akademik başarıya etkisi. (Yüksek lisans tezi). Atatürk Üniversitesi, Fen Bilimleri Enstitüsü, Fen Bilgisi Eğitimi Bilim Dalı, Erzurum.

Akçay, H. ve Baltacı, A. (2017). Astronomi öğretiminde öğrenme amaçlı çoklu yazma etkinliklerinin değerlendirilmesi. Mersin Üniversitesi Eğitim Fakültesi Dergisi,13(1), 138-151.

Aktepe, Z. T. (2020). Dördüncü sınıf maddeyi tanıyalım ünitesinde öğrenme amaçlı yazma etkinliklerinin akademik başarıya etkisinin araştırılması. (Doktora tezi). Atatürk Üniversitesi, Eğitim Bilimleri Enstitüsü, Sınıf Eğitimi Bilim Dalı, Erzurum.

Aktürk, F. (2018). Ortaokul 5 ve 8. sinıf öğrencilerinin ısı ve sıcaklık konusundaki kavram yanılgılarını belirlenmesinde mektup yazma aktivitesinin kullanılması. (Yüksek Lisans tezi). Giresun Üniversitesi, Fen Bilimleri Enstitüsü, Fen Bilgisi Eğitimi Bilim Dalı, Giresun.

Atila, M. E. (2008). Fen öğretiminde farklı betimleme modlarının öğrenme amaçl yazma aktivitelerinde kullanımlarının akademik başarıya etkisi. (Yüksek Lisans tezi). Atatürk Üniversitesi, Fen Bilimleri Enstitüsü, Fen Bilgisi Eğitimi Bilim Dalı, Erzurum.

Atila, M. E., Günel, M. ve Büyükkasap, E. (2010). Betimleme modlarının öğrenme amaçlı yazma aktiviteleri içerisindeki kullanım varyasyonlarının ilköğretim kuvvet ve hareket konularının öğrenimine etkisi. Türk Fen Ĕ̆itimi Dergisi, 7(4), 113-127.

Ay, A. (2018). Sosyal Bilgiler öğretim programında öğrenme amaçlı yazma etkinliklerinden mektup ve şïr kullanımının öğrenci başarısına etkisi. (Doktora tezi). Erzincan Üniversitesi, Sosyal Bilimler Enstitüsü, İlköğretim Bilim Dalı, Erzincan.

Aydın, A. (2018). Çoklu yazma etkinliklerinin ortaokul öğrencilerinin akademik başarısına ve fen bilimleri dersine yönelik tutumlarına etkisi. (Yüksek lisans tezi). Mersin Üniversitesi, Eğitim Bilimleri Enstitüsü, Fen Bilgisi Eğitimi Bilim Dalı, Mersin.

Balım, A. G., İnel, D. ve Evrekli, E. (2007). Probleme dayalı öğrenme (PDO) yönteminin kavram karikatürleriyle birlikte kullanımı: Fen ve teknoloji dersi etkinliği. Famagusta, Turkish Republic of Northern Cyprus: VI. International Educational Technologies Conference, Northern Cyprus. 
Baltacı, A. (2013). Astronomi konusunun çoklu yazma etkinlikleri ve yaparak yazarak bilim öğrenme metodu kullanlarak öğretilmesinin değerlendirilmesi. (Yüksek Lisans tezi). Marmara Üniversitesi, Eğitim Bilimleri Enstitüsü, Fen Bilgisi Öğretmenliği Bilim Dalı, İstanbul.

Baynazoğlu, L. ve Atasoy, E. (2020). Türkiye'de kavram karikatürleriyle ilgili yapılan araştırmalara yönelik bir meta-sentez çalışması. Cumhuriyet Uluslararası Ĕ̆itim Dergisi, 9(2), 390-409.

Biber, B. (2012). Fen ve teknoloji öğretmenlerinin yazmaya dair algılar ve öğrenme amaçl yazma aktivitelerini uygulama düzeyleri. (Yüksek Lisans tezi). Atatürk Üniversite, Eğitim Bilimleri Enstitüsü, Fen Bilgisi Eğitimi Bilim Dall, Erzurum.

Bozat, Ö. (2014). 5. Sinff yaşamımızdaki elektrik ünitesinde öğrenme amaçl yazma etkinliklerinden mektubun başarıya etkisi. (Yüksek Lisans tezi). Atatürk Üniversitesi, Eğitim Bilimleri Enstitüsü, Sınıf Öğretmenliği Bilim Dalı, Erzurum.

Bozat, Ö. ve Yıldız, A. (2015). 5. sınıf yaşamımızdaki elektrik ünitesinde öğrenme amaçlı yazma etkinliklerinden mektubun başarıya etkisi. Education Sciences, 10(4), 291- 304.

Budak, Y. (2016). Öğretim ilke ve yöntemleri (2. baskı). Ankara: Pegem Akademi.

Büyüköztürk, Ş., Kılıç Çakmak, E., Akgün, Ö.E., Karadeniz, Ş. ve Demirel, F. (2015). Bilimsel araştırma yöntemleri. Ankara: Pegem Akademi.

Çalık, M. ve Sözbilir, M. (2014). İçerik analizinin parametreleri. Eğitim ve Bilim, 39(174), 33-38.

Çakan-Akkaş, B. N. ve Kabataş-Memiş, E. (2020) Argümantasyon uygulamalarının 5. sinıf öğrencilerinin madde ve değişim ünitesi başarılarına ve bireysel değişimlerine yansıması. Kastamonu Ĕ̆itim Dergisi, 28(3), 1407-1417.

Çontay, E. G. (2012). Geometrik cisimlerin yüzey alanları ve hacimleri konusunda yazma etkinliklerinin 8. sinff öğrencilerinin başarllarına ve geometriye yönelik özyeterliklerine etkisi. (Yüksek Lisans tezi). Pamukkale Üniversitesi, Fen Bilimleri Enstitüsü, Matematik Eğitimi Bilim Dalı, Denizli.

Çömen, H. (2018). Fen bilimleri 7. smıf elektrik enerjisi ünitesi kapsamında öğrenme amaçl yazma aktivitelerine dayal geliştirilen hibrid kitabın etkilerinin incelenmesi. (Yüksek Lisans tezi). Uşak Üniversitesi, Fen Bilimleri Enstitüsü, Fen Bilgisi Eğitimi Bilim Dalı, Uşak. 
Daşdemir, İ. (2017). Öğrenme amaçlı mektup yazma aktivitesinin öğrencilerin akademik başarılarına, eleştirel düşünme becerilerine ve fizik tutumlarına etkisi. Uluslararası Bilimsel Araştırmalar Dergisi, 2(2), 262269.

Daşdemir, İ. (2018). İşbirliğine dayalı öğrenme ve öğrenme amaçlı mektup yazma aktivitesinin öğretmen adaylarının kuvvet ve hareket konusunda akademik başarılarına ve tutumlarına etkisi. Sakarya University Journal of Education, 8(3), 205-221.

Daşdemir, İ., Cengiz, E. ve Uzoğlu, M. (2015). Öğrenme amaçlı yazma aktivitelerinden mektup yazmanın 7 . Sınıf ışık ünitesinde öğrencilerin akademik başarılarına ve bilimsel tutumlarına etkisi. Ordu Üniversitesi Sosyal Bilimler Araştırma Dergisi, 5(11), 89-103.

Demir, M. (2012). Yaparak yazarak bilim öğrenimi- yybö yaklaşımının ilköğretim öğrencilerinin fen akademik başarılarına ve fen ve teknoloji dersine yönelik tutumlarına etkisi. Milli Eğitim Dergisi, 42(195), 146-165.

Demirel, T., Somyürek, S. ve Yılmaz, G. (2017). Ortaokul öğrencilerinin geometrik cisimler ve hacim ölçme konusuna yönelik yazılı argümantasyon becerilerinin incelenmesi. Ahi Evran Üniversitesi Kırşehir Eğitim Fakültesi Dergisi, 18(1), 191-211.

Doruk, B. K. (2015). Yaratıcı yazma etkinliklerinin matematik öğretmeni adaylarının sayılar konusundaki bilişsel yapılarına etkisinin incelenmesi. Abant İzzet Baysal Üniversitesi Ĕ̆itim Fakültesi Dergisi, 15(1), 105-128.

Duymaz, N. (2011). Hücre konusunun öğrenilmesinde öğrenme amaçl yazma etkinliklerinin kullanımı ve analoji üretme. (Yüksek Lisans tezi). Gazi Üniversitesi, Eğitim Bilimleri Enstitüsü, Biyoloji Eğitimi Bilim Dalı, Ankara.

Emig, J. (1977). Writing as a mode of learning. College Composition and Communitation, 28(2), 122-128.

Erduran, D. ve Akçay, T. (2013). Fen ve teknoloji dersinde yazma etkinlikleri üzerine öğretmen görüşleri. Türk Fen Eğitimi Dergisi, 10(2), 48-65.

Erkol, M. (2011). Yaparak yazarak bilim öğrenme yaklaşımının fen bilgisi öğretmen adaylarının fizik laboratuarı başarılarına etkisinin araştırılması. (Doktora tezi). Atatürk Üniversitesi, Eğitim Bilimleri Enstitüsü, Fizik Eğitimi Bilim Dalı, Erzurum. 
Erol, G. (2010). Asit baz konusunun çoklu yazma etkinlikleri ve yaparak yazarak bilim öğrenme metodu kullanlarak öğretilmesinin değerlendirilmesi. (Yüksek Lisans tezi). Marmara Üniversitesi, Eğitim Bilimleri Enstitüsü, Fen Bilgisi Öğretmenliği Bilim Dalı, İstanbul.

Gülcü, M. (2019). Illkokul öğrencilerinin biyoloji konuların modelleme ile öğrenme süreçlerinin incelenmesi. (Yüksek lisans tezi). Binali Yıldırım Üniversitesi, Sosyal Bilimler Enstitüsü, Sınıf Öğretmenliği Bilim Dalı, Erzincan.

Günel, M., Atila, M. E. ve Büyükkasap, E. (2009). Farklı betimleme modlarının öğrenme amaçlı yazma aktivitelerinde kullanımlarının 6.sınıf yaşamımızdaki elektrik konusunun öğrenimine etkisi. İlköğretim Online, 8(1), 183-199.

Günel, M., Kabataş-Memiş, E. ve Büyükkasap, E. (2009). Öğrenme amaçlı yazma aktivitelerinin ve analoji kurmanın üniversite düzeyinde mekanik konularını öğrenmeye etkisinin incelenmesi. Gazi Eğitim Fakültesi, 29(2), 401-419.

Günel, M., Kabataş-Memiş, E. ve Büyükkasap, E. (2010). Yaparak yazarak bilim öğrenme- YYBÖ yaklaşımının ilköğretim öğrencilerinin fen akademik başarısına ve fen ve teknoloji dersine yönelik tutumuna etkisi. Ĕ̆itim ve Bilim, 35(155), 49-62.

Günel, M., Uzoğlu, M. ve Büyükkasap, E. (2009). Öğrenme amaçlı yazma aktivitelerinin kullanımının ilköğretim seviyesinde kuvvet konusunu öğrenmeye etkisi. Gazi Eğitim Fakültesi Dergisi, 29(1), 379-399.

Hand, B. and Prain, V. (2002). Teachers Implementing writing to learn strategies in junior secondary science: A case study. Science Education, $86,737-755$.

Hand, B., Prain, V. and Vance, K. (1999). Writing to learn. Science Scope, 23(2), 21-23.

Homstad, T. and Thorson, H. (1996). Using writing-to-learn activities in the foreign language classroom (14. bask1). Minnesota: The Center for Interdisciplinary Studies of Writing, University of Minnesota.

İncirci, A. (2020). Öğrenme amaçl yazma etkinliklerinin güdülenme ve öğrenme stratejilerine etkisi. (Doktora tezi). Düzce Üniversitesi, Sosyal Bilimler Enstitüsü, Eğitim Programları ve Öğretimi Bilim Dalı, Düzce. 
Karaca, D. (2011). Yaparak yazarak bilim öğrenmenin (yybö) genel fizik laboratuarı-1 dersinde öğretmen adaylarını akademik başarılarına ve bilimsel süreç becerilerine etkisi. (Yüksek Lisans tezi). Mehmet Akif Ersoy Üniversitesi, Fen Bilimleri Enstitüsü, Fen Bilgisi Eğitimi Bilim Dalı, Burdur.

Karaçağıl, C. (2014). Sosyal Bilgiler derslerinde öğrenme amaçlı yazma etkinlikleri kullanımının öğrenci akademik başarısına etkisi. (Yüksek Lisans tezi). Sitkı Koçman Üniversitesi, Eğitim Bilimleri Enstitüsü, İlköğretim Eğitimi Bilim Dalı, Muğla.

Karaçağıl, C. ve Avaroğulları, A. (2017). Sosyal bilgiler derslerinde öğrenme amaçlı yazma etkinlikleri kullanımının öğrenci akademik başarısına etkisi. International Journal of Innovative Research in Education, 4(2), 5459.

Kasa, B. (2009). Yazma etkinliklerinin ilköğretim 1. kademe öğrencilerinin matematik başarılarına ve tutumlarına etkisi. (Yüksek Lisans tezi). Pamukkale Üniversitesi, Sosyal Bilimler Enstitüsü, Sınıf Öğretmenliği Bilim Dalı, Denizli.

Kavaklı, M. (2016). İnsan ve çeore ilişkileri ünitesinin çoklu yazma etkinlikleri kullanılarak öğretilmesinin değerlendirilmesi. (Yüksek Lisans tezi). Ömer Halisdemir Üniversitesi, Eğitim Bilimleri Enstitüsü, Fen Bilgisi Eğitimi Bilim Dalı, Niğde.

Kayaalp, F. (2020). Sosyal bilgiler dersinde öğrenme amaçl yazma etkinliklerini kullanmanın bilişsel ve duyuşsal öğrenmelere etkisi. (Doktora tezi). Atatürk Üniversitesi, Eğitim Bilimleri Enstitüsü, Sosyal Bilgiler Eğitimi Bilim Dalı, Erzurum.

Kieft, M., Rijlaarsdam, G. and Bergh, H.B. (2006). Writing as a learning tool: Testing the role of students' writing strategies. European Journal of Psychology of Education, 11(1), 17-34.

Klein, P. D. and Boscolo, P. (2016). Trends in research on writing as a learning activity. Journal of Writing Research, 7(3), 311-350.

Koçak, G. (2013). Tek boyutta hareket konusunda öğrenme amaçlı yazma etkinliklerinin uygulanmasının fen bilgisi öğretmenliği 1. sımı öğrencilerinin akademik başarısına ve kalıcllğa etkisi. (Yüksek Lisans tezi). Atatürk Üniversitesi, Eğitim Bilimleri Enstitüsü, Fen Bilgisi Eğitimi Bilim Dalı, Erzurum. 
Koçak, G. ve Seven, S. (2016). Fen bilgisi öğretmen adaylarının öğrenme amaçlı yazma etkinlikleri hakkındaki görüşleri: Tek boyutta hareket örneği. Ekev Akademi Dergisi, 20(65), 253-268.

Köksal, A. P. (2019). Öğrenme amaçlı yazma etkinliklerinin beşinci sımıf öğrencilerinin elektrik konusundaki akademik başarılarına, kalıcilğga ve fen bilimleri dersine karşı tutumlarına etkisi. (Yüksek Lisans tezi). Atatürk Üniversitesi, Eğitim Bilimleri Enstitüsü, Fen Bilgisi Eğitimi Bilim Dalı, Erzurum.

Küçük, M. (2019). Yazma etkinliklerinin matematik öğretiminde problem çözme becerisine, tutum ve kaygrya etkisi. (Yüksek Lisans tezi). Pamukkale Üniversitesi, Eğitim Bilimleri Enstitüsü, Eğitim Programları ve Öğretimi Bilim Dalı, Denizli.

Küçük, O. (2017). Sekizinci sımı öğrencilerinin epistemolojik inançlarının geliştirilmesinde yazma etkinliklerinin kullanılması. (Yüksek Lisans tezi). Recep Tayyip Erdoğan Üniversitesi, Fen Bilimleri Enstitüsü, Fen Bilgisi Eğitimi Bilim Dall, Rize.

Milli Eğitim Bakanlığı. (MEB). (2005). İlköğretim fen ve teknoloji dersi 4 ve 5. sinıflar öğretim programı. Ankara: MEB Yayınları.

Milli Eğitim Bakanlığı. (MEB). (2006). 17. milli eğitim şurası. Ankara: Talim ve Terbiye Kurulu Başkanlığı.

Milli Eğitim Bakanlığı. (MEB). (2006). İlköğretim fen ve teknoloji dersi 6. sinıf öğretim programı. Ankara.

Milli Eğitim Bakanlığı. (MEB). (2018). PISA 2018 Türkiye ön raporu. http://pisa.meb.gov.tr/wpcontent/uploads/2020/01/PISA_201_Turkiye_On Raporu.pdf adresinden erişilmiştir. 01.03.2021

Milli Eğitim Bakanlığı. (MEB). (2019). 2018-2019 LGS ortalamaları. https://www.memurlar.net/common/news/documents/837830/dosya.pdf adresinden erişilmiştir. 02.03.2021

Öğdük, A. (2011). Ilköğretim ikinci kademede fen ve teknoloji dersinde öğrenme amaçl yazma aktivitelerinde kullanilan modsal betimlemelerin akademik başarıya etkisi. (Yüksek lisans tezi). Atatürk Üniversitesi, Eğitim Bilimleri Enstitüsü, Fen Bilgisi Eğitimi Bilim Dalı, Erzurum.

Öz, M. (2015). Öğrenme amaçl yazma aktivitelerinde çoklu modsal betimleme kullanımının 5. sinıf öğrencilerinin öğrenmelerine, bilimsel süreç becerilerine, eleştirel düşünme becerilerine ve fen bilimlerine yönelik tutumlarma etkisi. (Yüksek lisans tezi). Kastamonu Üniversitesi, Fen Bilimleri Enstitüsü, İlköğretim Bilim Dalı, Kastamonu. 
Özbek, E. (2020). Bilimsel yazma etkinliklerinin ilköğretim 6. sinı öğrencilerinin bitki ve hayvanlarda üreme, büyüme, gelişme konusunda akademik başarılarına, fen bilimleri dersine ve yazıl anlatıma yönelik tutumlarına etkisi. (Yüksek lisans tezi). Marmara Üniversitesi, Eğitim Bilimleri Enstitüsü, Fen Bilgisi Öğretmenliği Bilim Dalı, İstanbul.

Özdemir, N. (2015). Fen öğretiminde yansıtıcı yazma etkinliklerinin öğrencilerin üst biliş becerilerine ve duyuşsal değişkenlere etkisi. (Yüksek lisans tezi). Dokuz Eylül Üniversitesi, Eğitim Bilimleri Enstitüsü, Fen Bilgisi Öğretmenliği Bilim Dalı, İzmir.

Özden, Y. (2020). Öğrenme ve öğretme (13. baskı). Ankara: Pegem Akademi.

Özkan, P. (2019). Öğrenme amaçl yazma etkinliklerinin 6. sinıf öğrencilerinin alan ölçme konusundaki kavrayışlarına etkisi. (Yüksek lisans tezi). Abant İzzet Baysal Üniversitesi, Eğitim Bilimleri Enstitüsü, Matematik Öğretmenliği Bilim Dalı, Bolu.

Öztürk, S. (2014). Lise 1 düzeyindeki öğrencilerin modsal betimlemeleri tanıyı öğrenme amaçl yazmada kullanmalarının fizik dersi dalgalar ünitesindeki akademik başarıya etkisi. Atatürk Üniversitesi, Eğitim Bilimleri Enstitüsü, Fen Bilgisi Eğitimi Bilim Dalı, Erzurum.

Öztürk, B. ve Günel, M. (2015). Öğretmen perspektifinden yazma ve yazmanın öğrenme amaçlı kullanımı: Ölçme envanteri geliştirme ve pilot uygulama. İlköğretim Online, 14(2), 712-733.

Öztürk, F., Öztürk, B ve Işık, A. (2016). Ortaokul matematik öğretmenlerinin yazmaya ve öğrenme amaçlı yazma aktivitelerine bakış açılarının belirlenmesi. Bayburt Ĕ̆itim Fakültesi Dergisi, 11(2), 306-328.

Özyurt, B. B. (2011). Canllarda üreme büyüme ve gelişme ünitesinin çoklu yazma etkinlikleri kullanularak öğretilmesinin değerlendirilmesi. (Yüksek lisans tezi). Marmara Üniversitesi, Eğitim Bilimleri Enstitüsü, Fen Bilgisi Öğretmenliği Bilim Dalı, İstanbul.

Pektaş, S. (2019). Yabancı dil öğretiminde öğrenme amaçlı yazma tekniğinin ögrrencilerin akademik başarı, tutum ve öz-yeterliklerine etkisinin incelenmesi. (Yüksek lisans tezi). Kocatepe Üniversitesi, Sosyal Bilimler Enstitüsü, Eğitim Programları ve Öğretimi Bilim Dalı, Afyon.

Pınar, E. (2019). Dördüncü stmıf fen bilimleri dersinde öğrenme amaçlı yazma etkinliklerinden günlü̆̈̈̈n başarıya ve fen tutumuna etkisi. (Yüksek lisans tezi). Atatürk Üniversitesi, Eğitim Bilimleri Enstitüsü, Sınıf Eğitimi Bilim Dalı, Erzurum. 
Polat, S. ve Ay, O. (2016). Meta-sentez: Kavramsal bir çözümleme. Eğitimde Nitel Araştirmalar Dergisi, 4(1), 52-64.

Reaves, R. R., Flowers, J. L. and Jewell, L. R. (1993). Effects of writing to learn activities on the content knowledge, retention, and attitudes of secondary vocational agriculture students. Journal of Agriculture Education, 1993(Fall), 34-40.

Sağırlı-Özturan, M. (2010). Öğrenci görüşlerine göre bazı yazma etkinliklerinin eğitsel etkilerinin incelenmesi. Educational Sciences: Theory \& Practice, 10(4), 2501-2530.

Sever, S. (2015). Türkçe öğretimi ve tam öğrenme (6. baskı). Ankara: Anı Yayıncilik.

Sezer, E. (2012). Matematik öğretimi dersi kapsaminda kullanılan yazma etkinliklerinin sınıföğretmeni adaylarının kesirler konusuna ilişkin pedagojik alan bilgilerine etkisinin incelenmesi. (Yüksek lisans tezi). Hacettepe Üniversitesi, Sosyal Bilimler Enstitüsü, İlköğretim Bilim Dalı, Ankara.

Şahin, S. (2019). Sosyal bilgiler derslerinde öğrenme amaçl yazma etkinliklerinden ders günlüğü kullanımının öğrenci başarısına ve kahıcilğa etkisi. (Yüksek lisans tezi). Binali Yıldırım Üniversitesi, Sosyal Bilimler Enstitüsü, Sosyal Bilgiler Eğitimi Bilim Dalı, Erzincan.

Tağa, T. (2018). Yazma etkinlikleriyle bütünleştirilmiş kelime öğretiminin kelime ögrrenme, hatırlama ve farknndalı̆̆a etkisi. (Doktora tezi). Gazi Üniversitesi, Eğitim Bilimleri Enstitüsü, Türkçe ve Sosyal Bilimler Eğitimi Bilim Dalı, Ankara.

Takaç, N. H. (2019). Farklı yazma aktivitelerinin kullanımınin 8. simı basit makineler konusunda öğrenci başarısı ve tutumuna etkisinin belirlenmesi. (Yüksek lisans tezi). Giresun Üniversitesi, Fen Bilimleri Enstitüsü, Fen Bilgisi Eğitimi Bilim Dalı, Giresun.

Tarikdaroğlu, T. (2019). Öğrenme amaçh yazmanın akademik başarıya etkisi ve ögrencilerin yazmaya yönelik tutumlarmın belirlenmesi. (Yüksek lisans tezi). Binali Yıldırım Üniversitesi, Fen Bilimleri Enstitüsü, Matematik ve Fen Bilimleri Eğitimi Bilim Dalı, Erzincan.

Tekin-Aytaş, Ç. (2012). Bir matematik sinıfındaki yazma aktivitelerine dayalı öğretim uygulamasının değerlendirilmesi. (Yüksek lisans tezi). Dokuz Eylül Üniversitesi, Eğitim Bilimleri Enstitüsü, Matematik Öğretmenliği Bilim Dalı, İzmir. 
Tekin-Aytaş, Ç ve Uğurel, I. (2016). Bir matematik sınıfındaki yazma aktivitelerine dayalı öğretim uygulamasının öğrencilerin öğrenmeleri üzerindeki etkileri. Milli Eğitim Dergisi, 211, 113-146.

Tümay, H. ve Köseoğlu, F. (2011). Kimya öğretmen adaylarının argümantasyon odaklı öğretim konusunda anlayışlarının geliştirilmesi. Türk Fen Eğitimi Dergisi, 8(3), 105- 119.

Türk Dil Kurumu (2021). Türk Dil Kurumu sözlükleri. https://sozluk.gov.tr/ web adresinden edinilmiştir. 02.03.2021

Uçar, Y. (2019). Öğrenme amaçl yazma etkinliklerinin öğrencilerin akademik başarlarına etkisi. (Yüksek lisans tezi). Atatürk Üniversitesi, Eğitim Bilimleri Enstitüsü, Sosyal Bilgiler Eğitimi Bilim Dalı, Erzurum.

Uğurel, I., Tekin, Ç. ve Morall, S. (2009). Matematik eğitimi literatürüden yazma aktiviteleri üzerine genel bir bakış. E-Journal Of New World Sciences Academy Education Sciences, 4(2), 494-507.

Ulu, C. ve Bayram, H. (2015). Yaparak yazarak bilim öğrenme yaklaşımına dayalı öğretim yönteminin bilimsel süreç becerilerine etkisi. Hacettepe Üniversitesi Ĕ̆itim Fakültesi Dergisi, 30(1), 282-298.

Uzoğlu, M. (2010). Öğrenme amaçl yazma aktivitelerinin kullanımının ilköğretim seviyesinde kuvvet ve madde ünitesini öğrenmeye etkisinin araştırlması. (Doktora tezi). Atatürk Üniversitesi, Fen Bilimleri Enstitüsü, İlköğretim Bilim Dalı, Erzurum.

Uzoğlu, M. (2014). Farklı öğrenme amaçlı yazma aktivitelerinin fen bilgisi öğretmen adaylarının akademik başarılarına, laboratuvar tutumlarına ve eleştirel düşünme becerilerine etkisi. Karadeniz Sosyal Bilimler Dergisi, 6, 195-209.

Uzoğlu, M. ve Aktürk, F. (2019). Beşinci sınıf öğrencilerinin 1sı ve sıcaklıkla ilgili kavram yanılgılarının belirlenmesinde mektup yazma aktivitesinin kullanılması. Kastamonu Eğitim Dergisi, 27(5), 2043-2055.

Uzoğlu, M. ve Gürbüz, F. (2013). Fen ve teknoloji öğretmen adaylarının ısı ve sıcaklık konusundaki kavram yanılgılarının belirlenmesinde öğrenme amaçlı mektup yazma aktivitesinin kullanılması. The Journal of Academic Social Science Studies, 6(4), 501- 517.

Uzun, S. ve Alev, N. (2013). Öğrenme amaçlı okuma-yazma etkinlikleri ile zenginleştirilmiş ortamların öğrenci başarısına etkisi. Türk Fen Eğitimi Dergisi, 10(2), 138-154.

Ünlü, V. (2015). 7. sinlf matematik dersi "olasilık ve istatistik" ögrenme alanında yazma etkinliklerinin öğrencilerin başarl, tutum ve üst bilişlerine etkisi. 
(Yüksek lisans tezi). Gazi Üniversitesi, Eğitim Bilimleri Enstitüsü, Matematik Öğretmenliği Bilim Dalı, Ankara.

Ünlü, V. ve Soylu, D. (2017). Ortaokul matematik dersinde yazma etkinliklerinin öğrencilerin başarı, tutum ve üst bilişlerine etkisi. Gazi Üniversitesi Gazi Ĕ̆itim Fakültesi Dergisi, 37(1), 345-360.

Yaman, F. (2018). Öğrenme amaçlı yazma etkinliklerinin ortaokul 6. sinıf öğrencilerinin madde ve isı ünitesindeki kavramsal anlamalarına etkisi. Sakarya University Journal of Education, 8(4), 89-108.

Yasul, A. F. (2019). Sosyal bilgiler dersinde kullanılan öğrenme amaçl yazma etkinliklerinin akademik başarıya, öğrenmenin kalıcilğına ve yazmaya yönelik tutuma etkisi. (Doktora tezi). Atatürk Üniversitesi, Eğitim Bilimleri Enstitüsü, Sınıf Eğitimi Bilim Dalı, Erzurum.

Yeşildağ, F. (2009). Modern fizik öğretiminde öğrencilerin çoklu modsal betimlemeleri algilamalarn ve modsal betimlemelerle hazırladiklarn yazma aktivitelerini değerlendirme sürecinin öğrenmeye etkisi. (Yüksek lisans tezi). Atatürk Üniversitesi, Fen Bilimleri Enstitüsü, İlköğretim Bilim Dalı, Erzurum.

Yıldırım, Z. (2016). Yazma etkinliklerinin ortaokul öğrencilerinin matematik başarılarına ve tutumlarma etkisi. (Yüksek lisans tezi). Kocaeli Üniversite, Fen Bilimleri Enstitüsü, İlköğretim Bilim Dalı, Kocaeli.

Yıldız, A. (2009). Üniversite öğrencilerinin kuantum fiziği konularmı anlama düzeyleri ve öğrenme amaçl yazma aktivitelerinin akademik başarıya etkisi. (Doktora tezi). Atatürk Üniversitesi, Fen Bilimleri Enstitüsü, İlköğretim Bilim Dalı, Erzurum.

Yıldız, A. (2014). Öğrenme amaçlı yazma aktivitesi olarak mektup ve etkili kullanım. Turkish Studies, 9(5), 2097-2104.

Yıldız, A. (2016). İlkokulda öğrenme amaçlı yazma etkinliklerinin akademik başarıya etkisinin tartışılması. Turkish Studies, 11(14), 861-870.

Yıldız, A. ve Büyükkasap, E. (2011a). Öğretmen adaylarının Compton olayını anlama düzeyleri ve öğrenme amaçlı yazma aktivitelerinin akademik başarıya etkisi. Uluslararası İnsan Bilimleri Dergisi, 8(1), 1643-1664.

Yıldız, A. ve Büyükkasap, E. (2011b). Öğretmen adaylarının belirsizlik ilkesini anlama düzeyleri ve öğrenme amaçlı yazmanın akademik başarıya etkisi. Türk Fen Ë̆̈itimi Dergisi, 8(4), 134-148.

Yıldız, A ve Büyükkasap, E. (2011c). Öğretmen adaylarının fotoelektrik olayını anlama düzeyleri ve öğrenme amaçlı yazmanın akademik başarıya etkisi. Kuram ve Uygulamada Ĕ̆itim Bilimleri, 11(4), 2259-2274. 
Yılmaz, N. (2014). Cebir öğretiminde yazma etkinliklerini kullanmanın ortaokul 7. sınıf öğrencilerinin başarılarına etkisi. Abant İzzet Baysal Üniversitesi Ĕ̆itim Fakültesi Dergisi, 15(1), 356-376.

\section{Kaynakça Bilgisi / Citation Information}

İspir, B. ve Yıldız, A. (2021). Türkiye'de öğrenme amaçlı yazma hakkında yapılan araştırmaların analizi: Bir meta-sentez çalışması. OPUSUluslararası Toplum Araştırmaları Dergisi, 18(41), 3396-3447. DOI: 10.26466/opus.906264. 